\title{
Ecological Guidelines and Recommendations for Mula-Mutha Riverfront Development
}

\author{
Dr. Swati Gole, Revati Gindi, Dhruwang Hingmire, Dr. Gurudas Nulkar
}

Dr. Swati Gole is Chairman and Co-founder of Ecological Society,Pune. She retired as Reader, Department of Geography, S.P.Collage Pune. Email : swatigole@gmail.com (Author for correspondence)

Revati Gindi is an alumnus of Ecological Society, Pune. She has done various courses in botany by Nisargsevak and Agharkar Institute Pune. Presently she is working as a consultant for ecological assessment and botanical projects and having experience with various organizations, NGOs and educational institutes.

Dhruwang Hingmire is an alumnus of Ecological society Pune and architect by profession. His practice aims to provide context specific, local architectural solutions drawing inspiration from vernacular system and using natural materials, local skills and techniques.

Dr. Gurudas Nulkar is a professor at Symbiosis International University and Ecological Society, Pune. He is the Endeavour Fellow of government of Australia. His research interests lie in alternatives to the current economic system, for sustainable development.

\begin{abstract}
This paper is a case of urban river Mutha for ecological management. Over the past few decades, condition of river Mutha has deteriorated considerably. The present situation shows less of fresh water flow and lot of sewage water addition,waste dumping and foul smelling water flow. The fresh water contribution by base flow to the main stream is very negligible. The only source of fresh water is sporadic water release from Khadakwasala dam. It is irregular and in small proportion to support ecosystem functioning of the river Mutha.There is a of public debate regarding improvement in the river's condition and to correct its root cause. The disruption in the river's ecosystem is basically by human interventions. The study appeals for interdisciplinary approach with a view of environmental governance and management to solve river related problems. The focus of this study is to assess environmental impact when the river related projects being planned by Municipal authorities. The study included survey of physical changes by human interventions, in the river Mutha channel ,banks and modification of habitats hampering aquatic as well as land biodiversity. The study indicated crucial biodiversity indicators for the health of the river ecosystem. By giving grades based on both the physical conditions and biodiversity of various stretches of the river plan to improve conditions is suggested. The study created guidelines for restoration and management of Mutha river ecosystem, which may be useful for rivers especially in the urban area. This paper is based on the research project "Ecological Guidelines and Recommendations for Mula-Mutha Riverfront Development" conducted by Ecological Society.
\end{abstract}

\section{Introduction}

The Mula and Mutha rivers originate in Western Ghats and flow through the Municipal boundaries of Pune city. Pune city is situated along the banks of River Mutha and Mula, which are integral of Pune's culture. Citizens of Pune are intimately connected with these rivers, and have a recreational, educational and religious connection with the river and are precious assets of our city. Till few decades ago river Mutha flowing through the old part of the city was clean, and a functioning ecosystem. The city used to derive benefits of this functional ecosystem. Functional river ecosystem is linked to its physical form and the character of water flow. However now human impact on both physical and flow character has created some severe problems like

- Water flow in the channel mostly consists of sewage resulting in foul-smelling water body.

- At places there is a carpet of excessively growing, non-native water hyacinth, and creating problem of mosquitoes. 
- The river flow is now not natural, completely controlled according to the necessity of water management of upstream dams. This results in redaction of flow during non-rainy season affecting biodiversity of the channel as well as banks.

- There are unwanted interventions without considering river as a natural physical system and ecosystem. River flow is channelized, making rest of the channel completely dry to harbor any biodiversity.

- The following examples of extreme change in the river system indicating disrespect to the river. The roads have been constructed in the channel itself. Besides roads channel floodplain converted into playgrounds and parking at various places. Red flood line is also not respected. Construction within red flood line is seen at some places.

Most of the problems mentioned above were realized approximately in 1970s. The intensity of those problems were much less though than the present condition. In order to resolve those problems hypothetical plan was designed based on actual river survey by Shri Prakash Gole. (Gole, 1983)

The study of all these problems in greater depth and to suggest nature- centric solutions, Ecological Society conducted a survey in the year 2018. The objective of the survey was to see present condition of the river as an ecosystem, status of cultural and religious structures, non-desirable interventions within the channel and the banks. The approach for this study is to have deeper understanding of the river ecosystem from the perspective of native biodiversity value, ecosystem services provided by the river and to search appropriate riverfront design which can satisfy citizen's requirements without compromising river's ecosystem functioning. The Pune Municipal Corporation also proposed project to develop Mutha and Mula riverfront. The design for this project on the website of PMC shows major interventions. The objective of this project is to control floods, increase in land value along the banks for commercial purpose, and creation of recreational places. This may lead to ignoring other functionalities of the river, which is not in the interest of river ecosystem itself and the public. The additional angle to Ecological Society's study was then to examine pros and cons of the PMC's "River Front Development" project. The CEE (Center for Environmental Education), the prominent organization working in environmental education in India, supported this project.

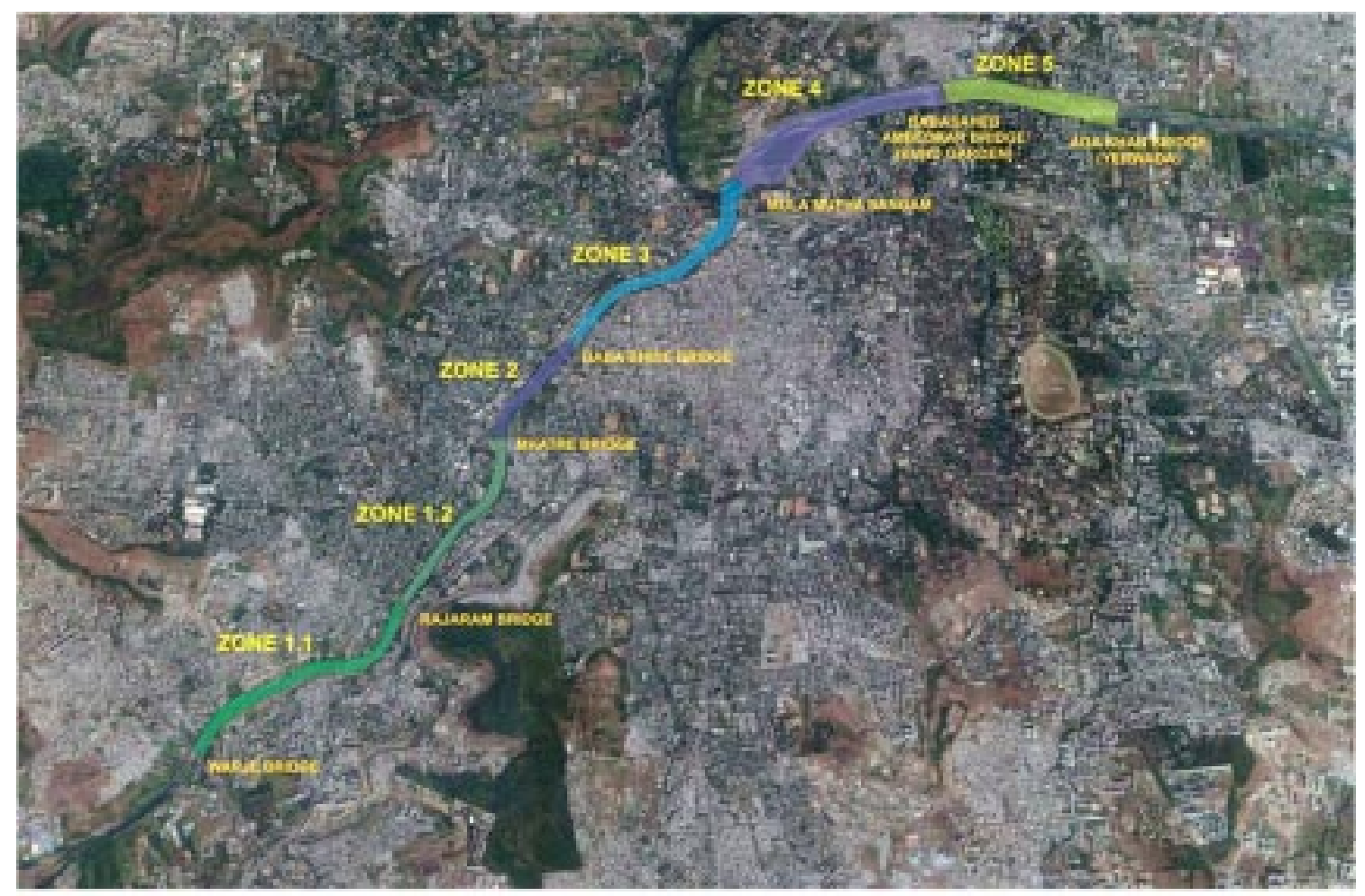

Map of the surveyed zones. 


\section{Geographical Area of the Study}

The section of approximately $22 \mathrm{~km}$. long stretch of river Mula-Mutha flowing through boundaries of Pune city was selected. The survey was conducted between Warje Bridge to Agakhan Bridge. (See google map No. 1 of the surveyed area.) For study purpose the river from
Warje Bridge to Yerawada Bridge was divided into five zones, based on its physical and biological character. The physical character includes channel parameters, such as its cross section, width and height, substratum and habitats created by the rivers. The biotic elements survey includes aquatic vegetation, riparian vegetation study and its mapping. Observations regarding asso-

\section{Flowchart depicting methodology}

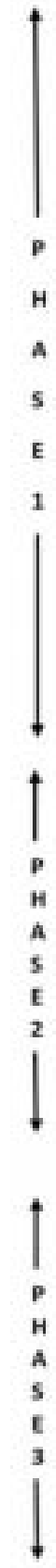

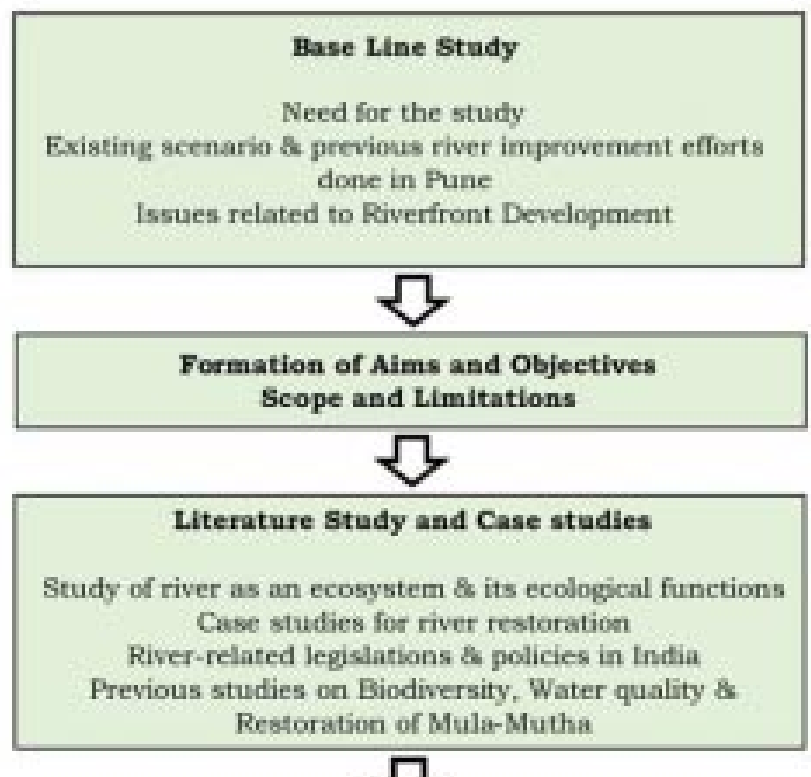

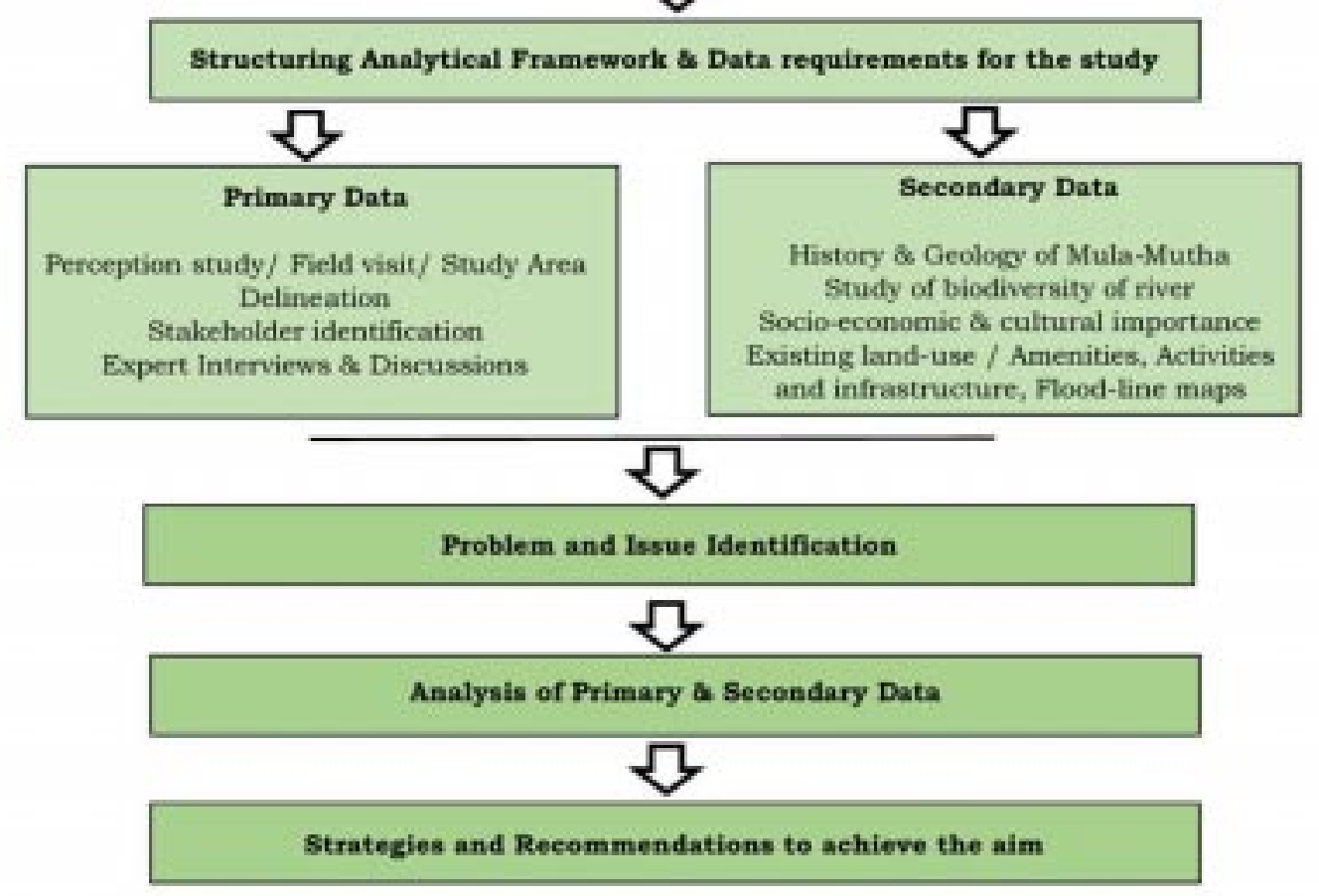


ciation between riverine habitats and aquatic vegetation and fauna were documented. Riverine avifauna is a good indicator to see the state of aquatic fauna and habitat diversity within the channel and banks. Therefore, exercise of mapping and documentation of bird species, their number and nesting sites could give us good insight of Mutha river ecosystem.

The $22 \mathrm{~km}$ long stretch of river Mutha was subdivided into five zones for survey purpose.

Zone 1: This was further divided into two parts i.e.1.1 and 1.2

Zone 1.1 : Warje Bridge (on Pune-Mumbai Highway) to Rajaram Bridge

Zone 1.2 : Rajaram Bridge to Mhatre Bridge

Zone 2 : Mhatre Bridge to Baba Bhide Bridge

Zone 3 : Baba Bhide Bridge to Mula-Mutha Sangam

Zone 4 : Mula-Mutha Sangam to Ambedkar Bridge (Bund Garden)

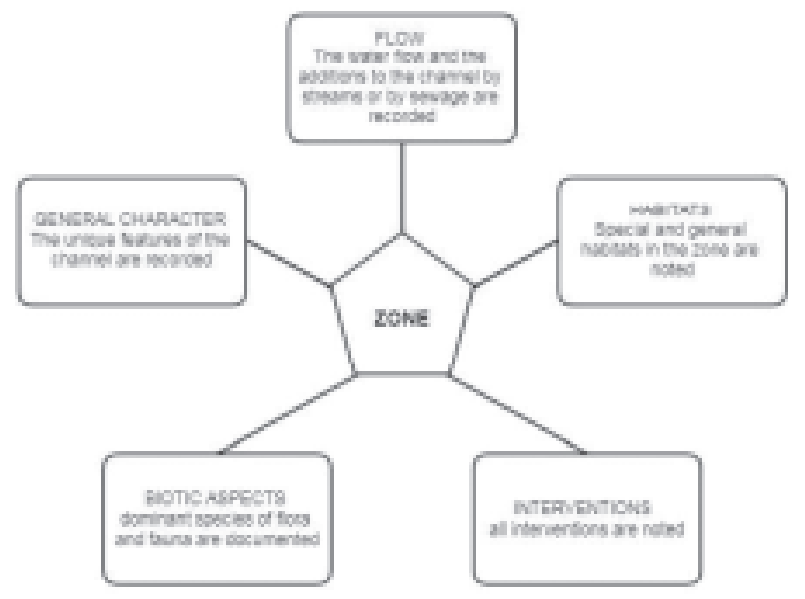

Fig. 2
Zone 5 : Babasaheb Ambedkar Bridge to Aga Khan Bridge (Yerwada)

\section{Methodology}

The methodology employed for this study is depicted in Fig. 1. The study was divided into three phases mentioned in Fig. 1.

The parameters shown in Fig. 2 were considered for the study of each zone

Based on all the above parameters all these zones were assessed for ecological health. For assessment of flora the standard literature was used such as Flora of Maharashtra state by Botanical Survey Of India and various field guides for fauna.

Out of five zones only zone 1.1 is described in this article as an example as follows :

\section{Zone 1.1 : Warje Bridge to Rajaram Bridge}

\section{A: Physical Character}

i: Channel Character

The channel in this zone is sinuous with westward bend near Vitthalwadi mandir. The cross section of the river here is asymmetric, having steeper slope on right side and gentler on the left. Large part of the channel is rocky. Potholes are a predominant habitat on the righthand side of the channel created by erosion process. The left side of the channel is characterized by low lying sediment deposition creating marshy areas.

ii: Flow Character

The river in this part is flowing through the constructed wall causing constriction and rapid flow. This channelized mainstream receives large quantities of sewage water from the city. Downstream of the

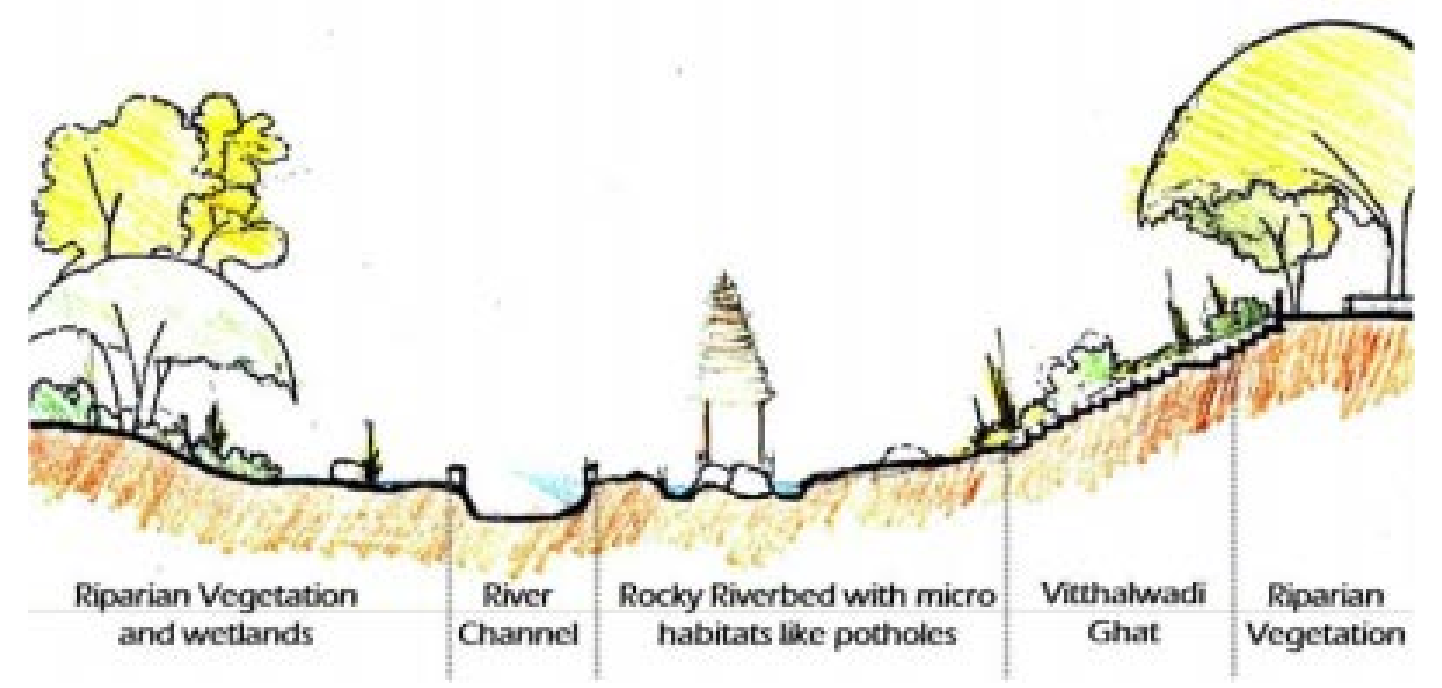

Fig. 3 : Cross Section of the River Mutha at Vitthalvadi 
channelized part of the river, channel is characterized by various habitats. These habitats receive water only during monsoon floods or short seasonal pulses created by rainfall in the surrounding area. There is also a "press event" where during monsoon large quantities of water are released from the Khadakwasala dam. Many species of aquatic vegetation and fauna cannot adjust to such erratic flooding.

The Mula-Mutha river survey conducted by ecological society in 1982, "Survey of the rivers in the Pune city based on ecological factors in order to prepare an Eco-development plan to improve the river fronts of Pune" by author Prakash Gole. This report describes river flow near Vittal Mandir Zone as follows: "Once over the rocky outcrop the stream at Vithalwadi flows sluggishly (240 mtrs/hour), eddying softly over submerged rocks and lapping against small inlets in Basalt which at places are sufficiently broad to make sheltered coves and bays." This shows the riverbed used to receive natural flow till as recent as 1982.

iii. Habitats

Stretch of river between Warje and Vithalwadi hosts various types of habitats such as exposed rocks in riverbed, potholes, elongated cracks on exposed rocks, marshy areas, open grassy patches, deep pools, feeding streams, small riparian patches, meanders, riffles and pools etc. This indicates a good diversity of habitats.

\section{B: Biotic Character}

\section{i. Flora}

Corresponding to the high diversity of habitats, high floral diversity was observed in this zone. e.g. the marshy habitat supports species like Colocasia, Typha, Canna, Ludwigia, Hygrophila etc.Riparian habitats include stunted growth of Ficus racemosa, Acacia, Syzygium, Pongamiaspp. associated with nonnative and aggressive shrubs like Lantana, Eupatorium etc. In rock cracks herbaceous growth of Leucas biflora, Cleome spp. associated with few grasses were observed.Along the edges of feeding streams observed typical vegetation of Ficus racemosa, Phyllanthus reticulatus, Persicaria, Colocasia, etc. Also found pure formations of Xanthium in open patches occasionally and few open patches dominated by grass species. Invasive species water hyacinth is found in patches. Of the six zones, this zone has the maximum floral diversity.

ii. Fauna

In small riparian patches and dense shrubbery areas, birds like Prinia, Drongos, and Sunbirds, Bush chats, Indian robin were observed. Swallows were seen flying over the water surface and wagtails walking in marshy areas through Persicaria. In open patches Yellow wattle lapwings were in large numbers. Normally it is not found and therefore an important species in terms of diversity. Its roosting as well as nesting was sighted. In the channel-bed Spot bill ducks, Pond Herons, Black winged stilts were observed. White breasted kingfisher more versatile using several habitats like flowing water, riparian and channel walls. Presence of Black winged stilts and Pond heron indicates highly polluted water. Sighting of Red Munia indicate good marshy areas with Typha providing their Roosting places and open grassy patches for feeding. A rare sighting of the Cinnamon bittern indicates good marshy habitats in those areas. Wooly necked stork, Painted stork observed sometimes in open grassy patches on the banks. Numbers of scavenging birds like Crows, Black kites, were observed in large numbers because there is solid -waste dumping at many places in the channel bed and bank. Habitat diversity is good in this stretch and so the bird species show good diversity but in small number in this zone. This may be because indigenous fish diversity in the flow is almost absent. (Wagh \& Ghate, 2003). According to the local fishermen near Vitthal mandir, species like "Maral" which feeds on sewage are dominant. This is a nonnative, introduced species, and the growth is rampant in the sewage laden river flow.

Documentation and its mapping on Landsat imagery (Google Map 2) of flora and fauna led to identification of biodiversity hotspots in each zone. In the same image cultural entities were mapped. The example of zone 1.1 having good number of hotspots is given below.

\section{C: Biodiversity hotspots}

A Biodiversity hotspot according to the Botanical Survey of India is "Hotspot is a biogeography region that is both a significant reservoir of biodiversity and is threatened with distraction." The entire zone has many important ecological features. These are critically important parts of the river ecosystem. These places are highly vulnerable and irreplaceable therefore valuable. One cannot afford to lose these features for the proper functioning of the river ecosystem. This survey also assessed which hotspots are degraded, its extent of degradation and threatened. The extent of degradation is important, so that the kind of solution can be decided. The types of hotspots considered are those which are important for river ecosystem functioning.

Biodiversity hotspots -

1.a Rocky banks

1.b Feeder stream mouths 


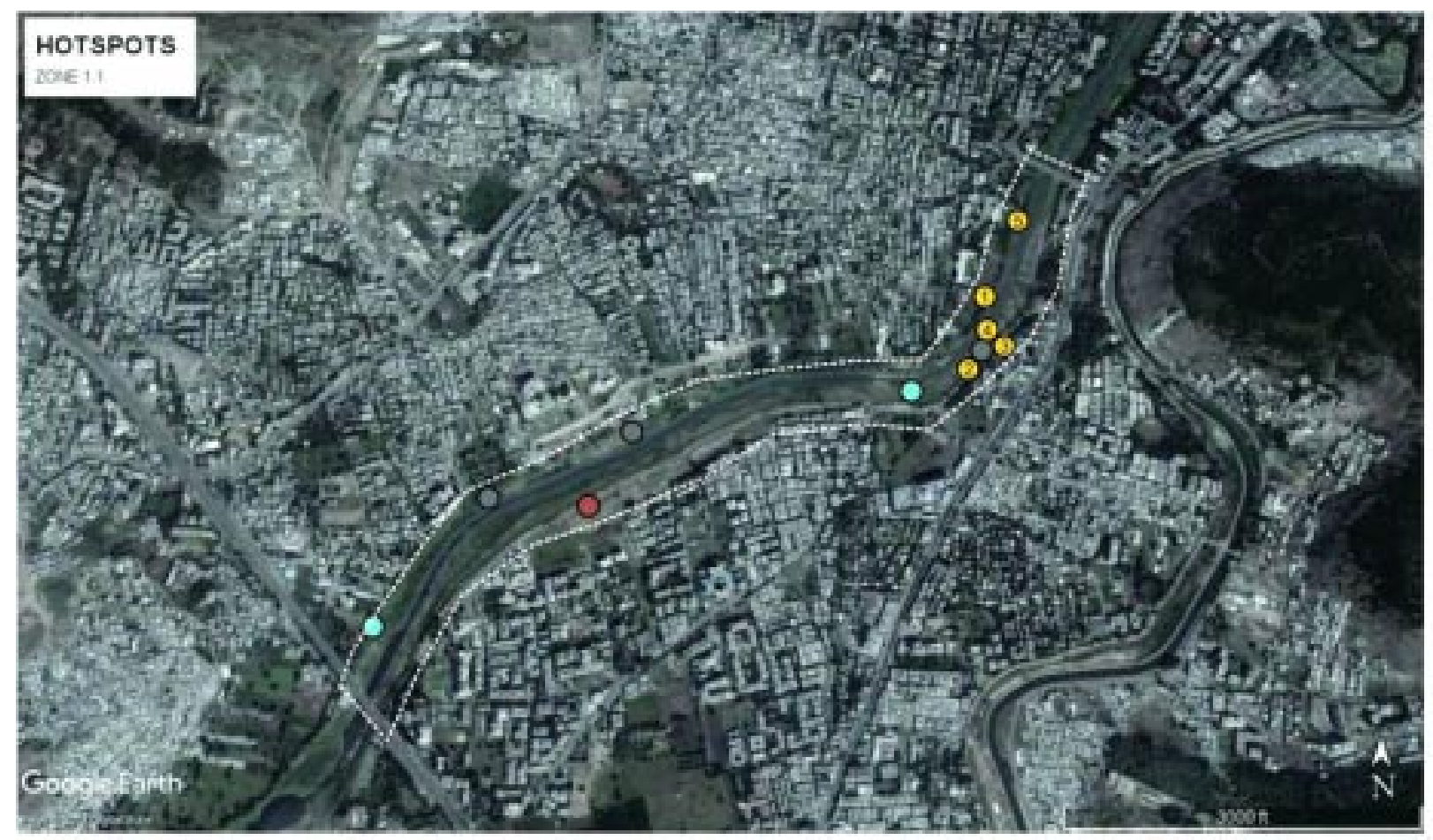

Q. RED WATTLED LAPWNG ROOST

O. RED ANADAVAT ROOST

O. SPOTTED OWLET ROOST

(ब. WHITE BROWED WAGTAIL ROOST

5. PURPLE HERON ROOST

ROCKY BANK HOTSPOT

FEEDER STREAM MOUTH

8 ALLUVIAL PLANS

$O$ GRASSY PATCH

GIPARIAN VEGETATION

O FAUNA HOTSPOT

8 CULTURAL HOTSPOT

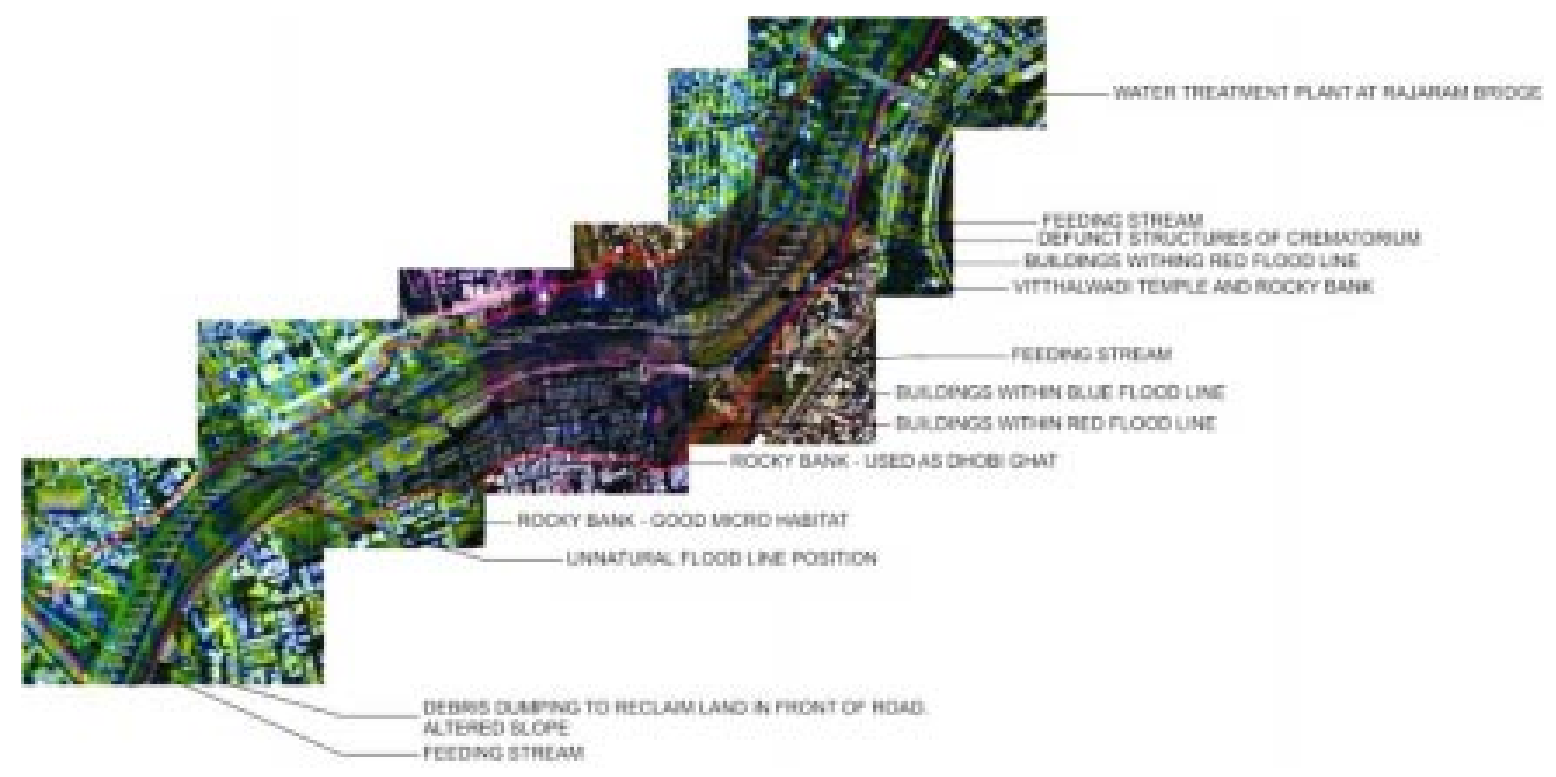

Google Map 2: Zone 1.1: Warje Bridge to Rajaram Bridge 
1.c Alluvial filled surfaces

1.d Grassy patches

1.e Riparian habitats

1.f Faunal hotspots

\section{Cultural hotspots}

Pune being historic city there are religious and cultural structures along the river. Besides temples there are Ghats and memorial structures. As all these form heritages of the Pune City, they become cultural hotspots.

\section{E. Current status of the Zones}

i Unfair use of river channel and water by citizens and administration in the following way:

- Dumping and burning of Garbage

- Dumping of construction debris

- Bank scraping

- Incorrect marking of flood lines

- Encroachments and Construction within flood lines

- Encroachments, dumping, hardscaping and narrowing of tributary feeding Streams

- Channelization of the river flow

- Defunct structures in riverbed

- Construction of roads in the channel flood plain
- Allotment of sizeable space in the channel floodplain for parking of vehicles and play grounds.

All these unfair uses are responsible for malfunctioning of hydrological as well as ecological processes. They also indicate disregard of the beauty and sanctity of the river.

\section{Assessment of the Surveyed Zones}

The next step after the data collection and observations is to assess all these zones qualitatively. The following is the methodology to determine quality of the zones.

\section{Qualitative Assessment of Zones}

For qualitative assessment of zones, biodiversity documentation as well as channel characteristics and human interventions were considered. It facilitated ranking of these zones showing its ecological health.

\section{Methodology}

The physical and biological aspects observed of these five zones were significantly different from each other. For an effective recommendation plan, it is necessary to bring them on a common assessment platform.Therefore, use of relative rating is used. Rating of each zone was based on nine parameters and the

Table 1 : Qualitative Assessment of the Zones

\begin{tabular}{|l|l|l|l|l|l|l|l|}
\hline \multicolumn{9}{|c|}{ Stretch-wise Quality Assessment } \\
\hline & Rating & Zone 1.1 & Zone 1.2 & Zone 2 & Zone 3 & Zone 4 & Zone 5 \\
\hline Channel & Range 0-5 & 3 & 2 & 0 & 1 & 4 & 5 \\
\hline Flow & Range 0-5 & 3 & 2 & 0 & 1 & 4 & 5 \\
\hline Habitat diversity & Range 0-5 & 4 & 2 & 1 & 0 & 3 & 5 \\
\hline Floral diversity & Range 0-5 & 4 & 2 & 1 & 0 & 5 & 3 \\
\hline Bird diversity & Range 0-5 & 3 & 2 & 1 & 0 & 4 & 5 \\
\hline Solid waste dumping & Yes=0, No=1 & 0 & 0 & 0 & 0 & 0 & 1 \\
\hline Encroachment & Yes=0, No=1 & 0 & 0 & 1 & 1 & 1 & 1 \\
\hline Human disturbance & Range 0-5 & 3 & 2 & 0 & 1 & 4 & 5 \\
\hline $\begin{array}{l}\text { Roads/intervention } \\
\text { in channel }\end{array}$ & No=1; Yes=0 & 0 & 0 & 0 & 1 & 1 & 1 \\
\hline Total Marks per Zone & $\mathbf{3 8}$ & $\mathbf{2 0}$ & $\mathbf{1 2}$ & $\mathbf{4}$ & $\mathbf{5}$ & $\mathbf{2 6}$ & $\mathbf{3 1}$ \\
\hline Percent score & & $\mathbf{5 2 . 6 3}$ & $\mathbf{3 1 . 5 8}$ & $\mathbf{1 0 . 5 3}$ & $\mathbf{1 3 . 1 6}$ & $\mathbf{6 8 . 4 2}$ & $\mathbf{8 1 . 5 8}$ \\
\hline
\end{tabular}


Table 2 : Grading of zones for ecological health

\begin{tabular}{|c|c|c|}
\hline $\begin{array}{l}\text { Grade } 1 \text { zones with relatively high } \\
\text { ecological value Score }>66 \%\end{array}$ & $\begin{array}{l}\text { Grade } 2 \text { zones with a relatively } \\
\text { medium ecological value Score } \\
\text { between } 30-65 \%\end{array}$ & $\begin{array}{l}\text { Grade } 3 \text { zones with the least } \\
\text { relative ecological value Score } \\
<33 \%\end{array}$ \\
\hline $\begin{array}{l}\text { Zone } 5 \\
\text { A. Strengths } \\
\text { 1. Channel character and flow } \\
\text { 2. Habitat diversity and bird } \\
\text { diversity } \\
\text { 3. Minimum solid waste dumping, } \\
\text { encroachment, human disturbance } \\
\text { and roads / interventions in } \\
\text { channel. } \\
\text { B. Opportunities } \\
\text { 1. Floral diversity quality can be } \\
\text { improved. } \\
\text { C. Weakness/Threats } \\
\text { 1. Nothing significant }\end{array}$ & $\begin{array}{l}\text { Zone } \mathbf{1 . 2} \\
\text { A. Strengths } \\
\text { 1. Habitat and floral diversity } \\
\text { B. Opportunities } \\
\text { 1. Channel character, Flow, Bird } \\
\text { diversity and moderate human } \\
\text { disturbance } \\
\text { C. Weakness/Threats } \\
\text { 1. Solid waste dumping, encroach- } \\
\text { ment and roads in river channel. }\end{array}$ & $\begin{array}{l}\text { Zone } 3 \\
\text { A : Strengths } \\
1 \text {. Nothing significant. } \\
\text { B : Opportunities 1. Channel, flow, } \\
\text { habitat diversity, floral diversity, } \\
\text { bird diversity, moderate human } \\
\text { disturbance } \\
\text { C : Weakness/Threats } \\
\text { 1. Solid waste dumping, encroach- } \\
\text { ments and roads / interventions in } \\
\text { river channel }\end{array}$ \\
\hline $\begin{array}{l}\text { Zone } 4 \\
\text { A : Strengths } \\
\text { 1. Floral diversity is the best } 2 . \\
\text { Minimum disturbance and en- } \\
\text { croachment } 3 \text {. Naik island } 4 . \\
\text { Channel character, Flow, } \\
\text { Biodiversity are strengths. } \\
\text { B : Opportunities } \\
\text { 1.Solid waste dumping to be } \\
\text { stopped, protection of habitats from } \\
\text { stresses induced due to grazing } \\
\text { and open defecation. } \\
\text { C. Weakness/Threats } \\
\text { 1. Nothing significant }\end{array}$ & $\begin{array}{l}\text { Zone } 1.1 \\
\text { A : Strengths } \\
\text { 1. Nothing significant. } \\
\text { B : Opportunities } \\
\text { 1. Channel, flow, habitat diversity, } \\
\text { floral diversity, bird diversity, } \\
\text { moderate human disturbance } \\
\text { C : Weakness/Threats } \\
\text { 1. Solid waste dumping, encroach- } \\
\text { ments and roads / interventions in } \\
\text { river channel }\end{array}$ & $\begin{array}{l}\text { Zone } 2 \\
\text { A : Strengths } \\
\text { 1. No encroachments } \\
\text { B : Opportunities } \\
\text { 1. Poor biodiversity } \\
\text { C: Weakness/Threats } \\
\text { 1. Channel characters, flow, solid } \\
\text { waste dumping, human } \\
\text { disturbance and roads / } \\
\text { intervention in channel. }\end{array}$ \\
\hline
\end{tabular}

existence of hotspots. The scale for rating was between the values ranging between 0 and 5 . Here high marks representing the higher value.

The results shown in Table 1 are as follows: The maximum marks possible for each zone is 38 . The marks were converted into percentage score. The table given below shows the assessment.

Based on the scored percentage, each zone was graded into three grades viz.1, 2 and 3. Grade 1 zone is assigned to relatively high ecological value greater than Score $>66 \%$. Grade 2 zones with a relatively medium ecological value Score ranging between 30$65 \%$. Grade 3 zones with the least relative ecological value Score $<33 \%$. The details of grades are shown in
Table 2.

Grading of the Zones: To determine following grades, hydrological and biological strengths, opportunities and weakness of the zones were considered.

Based on the qualitative assessment and grading of the zones, broad strategy is proposed for each zone. These strategies led further to form guidelines for PMC to follow.

1 Grade 1 : Zones 4 and 5 :

Suggested Strategy : No interventions and a benign neglect

In these zones active restoration may be unnecessary as hydrological conditions are better, the channel is in natural condition with high habitat diversity. Not 
significant interventions. In such a situation undisturbed recovery is suggested in this zone. These zones have a potential to recover by benign neglect but with strict protection for these zones. These zones can be designated as special zones having extremely high bird diversity associated with it. There were efforts to conserve and protect these zones by proposing sanctuary in a zone having extremely high biological value. It is necessary to take help of experts and the following steps are sufficient for the revival of this zone.

1 Conservation of aquifer discharge areas (natural springs).

2 Conservation of heritage sites such as ghats, places of worship, samadhis and memorials.

3 Conservation of all in-stream habitats like rocky patches, potholes, ponds, islands.

4 Upland zones, Riparian zones.

5 Areas deep soil profile be preserved as it has a great value of retaining climatic history through geological time. Such climatic history is in scripted in sediment deposits along the riverbank.

6 Conservation of faunal hotspots like roosting and nesting sites.

7 Restriction on human and cattle access, and provision of alternative grazing area.

\section{Grade2 : Zones 1.2 and 1.1 :}

\section{Suggested Strategy : Partial intervention}

Natural processes in the river corridor of these zones are relatively intact. Its potential to improve ecological conditions is high. Therefore, partial intervention is suggested. The partial intervention involves retention of existing habitat and its improvement. Unnecessary manmade interventions which are affecting river functioning are suggested to remove.

\section{Grade 3 : Zones 2 and 3 :}

\section{Suggested Strategy : Substantial intervention}

Zones in this grade are in a relatively poor ecological state and require substantial intervention for a managed recovery. In such a case intervention related to active restoration methods can be employed. This includes :

1 Measures for bank stability using restoration measures.

2 Improvement in the water quality of tributary stream by techniques like green bridges or biofiltration.

3 Habitat creation - within the-stream, on the banks and on the upland using restoration methods.

4 Removal of existing interventions that affect functioning of river/stream ecosystem.
5 Removal of encroachments, waste and debris dumping.

6 Creation of aquifer recharge areas with the help of hydrogeologist.

7 Creation of extensive Riparian zones by planting appropriate indigenous varieties of plants.

Vision for the rejuvenation of Mula and Mutha river ecosystem

This proposed "River Front Development "plan by PMC shows major interventions within the channel and on the banks. Such interventions disregard the river's hydrological and ecosystem values. It is therefore necessary to put forth guidelines for river front development which can be nature centric. An effort is made to incorporate ecological design in the riverfront development plan.

While suggesting ecological development for Mula and Mutha the rationale is to make river naturally flowing with its ecological functions. To overcome, both hydrological and ecological problems of river Mula-Mutha, restoration of river system appears to be best practical solution. For suggesting this one must consider that river is not an isolated single stream, but it is a part of a natural drainage system. It also has a connection with the surroundings. The extent of area adjacent to river where river processes happen is called as river corridor. The definition of river corridor is as follows: -

"River Corridor" means the land area adjacent to a river that is required to accommodate the dimensions, slope, planform, and buffer of the naturally stable channel and that is necessary for the natural maintenance or natural restoration of a dynamic equilibrium condition" ref. - it is defined in section 1422 of this title, and for minimization of fluvial erosion hazards, as delineated by the Agency of Natural Resources in accordance with river corridor protection procedures. (10 V.S.A. Chapter $32 \S 752$.

In case of riverfront Development of the Mula Mutha, it is essential to address the river along with its tributary streams. The services provided by the river are many, and it is unwise to lose these services by riverfront development project. The following is the array of services provided by the river :

They provide water supply for drinking, and other household uses, power generation and industrial uses, supply of Fish, non-extractive or in- stream benefits as flood control, transportation, birds and wildlife habitat, recreational facilities, pollution dilution, enhanced property values etc., critical ecological functions like ground water recharge, modulating stream flow etc. If 
there are major changes in the flow of the river these functions are almost lost. However, those can be reestablished by employing proper restoration techniques. Following image shows the role of various organisms in the functioning of river ecosystem.

\section{Holistic view for river rejuvenation}

\section{A: Conservation of the river as a natural entity.}

This necessitates that the ecological value must be prioritized over the economic utility arising from the river. The proposed interventions must respond to this natural context sensitively, and not cause any major deviations to these functions.

We recommend that utmost importance be given to the restoration of the natural design of the river, over human-centric built designs. This would not only make the project unique but also contribute to the ecological value accrued by the city.

\section{B: Restoration of natural zones along the river}

The restoration process includes rejuvenation of the structure, function and self-sustaining behavior of the river ecosystem. Following restoration strategies must be applied in stages and corresponding to the ecological status of each zone.

1. Substantial intervention for managed recovery

2. Partial intervention for assisted recovery

3. Non-intervention and undisturbed recovery

\section{C: Maintaining environmental flow and carrying capacity}

It is of prime importance to maintain the minimum requirement of environmental flow for sustenance of the river ecosystem. Mula-Mutha water flow is controlled by Khadakwasala dam. The river flow is erratic and environmental flow is many times absent causing the loss of habitats and biodiversity. It is therefore necessary to maintain environmental flow by releasing water from Khadakwasala dam.

\section{D: Decentralized approach to river rejuvenation}

Tributary streams joining Mula-Mutha contribute significant amount of water. These feeding streams are most important feature of the Mula-Mutha ecosystem. Historically, the southern tributaries like Ambil, Nagzari contributed large quantities of water to the river. Today, these tributaries are encroached upon and this has resulted into limited recharge of groundwater aquifers, reduction in the natural flow and large contribution of sewage water through these streams to the mainstream. Recent unusual floods affecting areas adjacent to these tributaries show importance of natural flow without any unfair changes in the tributary streams. Therefore, restoration of these feeding streams is also essential in the planning. And issues such as those relating to dumping of debris, solid waste, sewage and other unwarranted activities, should be urgently addressed at the catchment level.

\section{E: Restoration for utility and aesthetic value}

Restoration of the river ecosystem is important, however, to enjoy serene beauty of the river, some spaces with aesthetic value can be created along the bank without disturbing its natural ecosystem. Maintaining water quality is important for enhancing visual appeal of the riverfront. This will help the river to host macro and micro habitats for a wide array of flora and fauna. There is an immense potential for activities like bird watching, insect trails, herpetology studies along the riverbanks.

\section{Guidelines and recommendations to re-establish river system}

\section{Flora and Fauna}

i. While restoring the habitats care should be taken for selection of plant species and its location. Reintroduction of species of aquatic flora which are lost is essential. Refer to the list given in report "Survey of rivers in Pune city based on ecological factors to prepare an eco-development plan to improve the river fronts of the Pune" (Gole P.1983)

ii. Plantation can be done only in riparian zone and in upland area. But for selection of plant species and its location we recommend that the study of the flora of the Mutha River-Bed near Poona by V.D. Vartak (1958) and Studies on the Aquatic flowering Plants from greater Pune Area : Part I, enumeration by Vinaya Ghate and V.D.Vartak (1981) is very important. Also, recommended vegetation species for plantation in riparian and upland area in the annexure.

iii. A periodic management is necessary for complete removal of weeds.

iv. If any plantation of vegetation is to be proposed as a part of the Riverfront/Rejuvenation Project, the flora native and with respect to these respective habitats alone must be considered. Refer to Fig. 4 .

v. Plantation of non-native species of flora and introduction of non-native faunal species must be strictly avoided.

\section{Habitat Creation}

The flow and flood rhythm of rivers create micro 


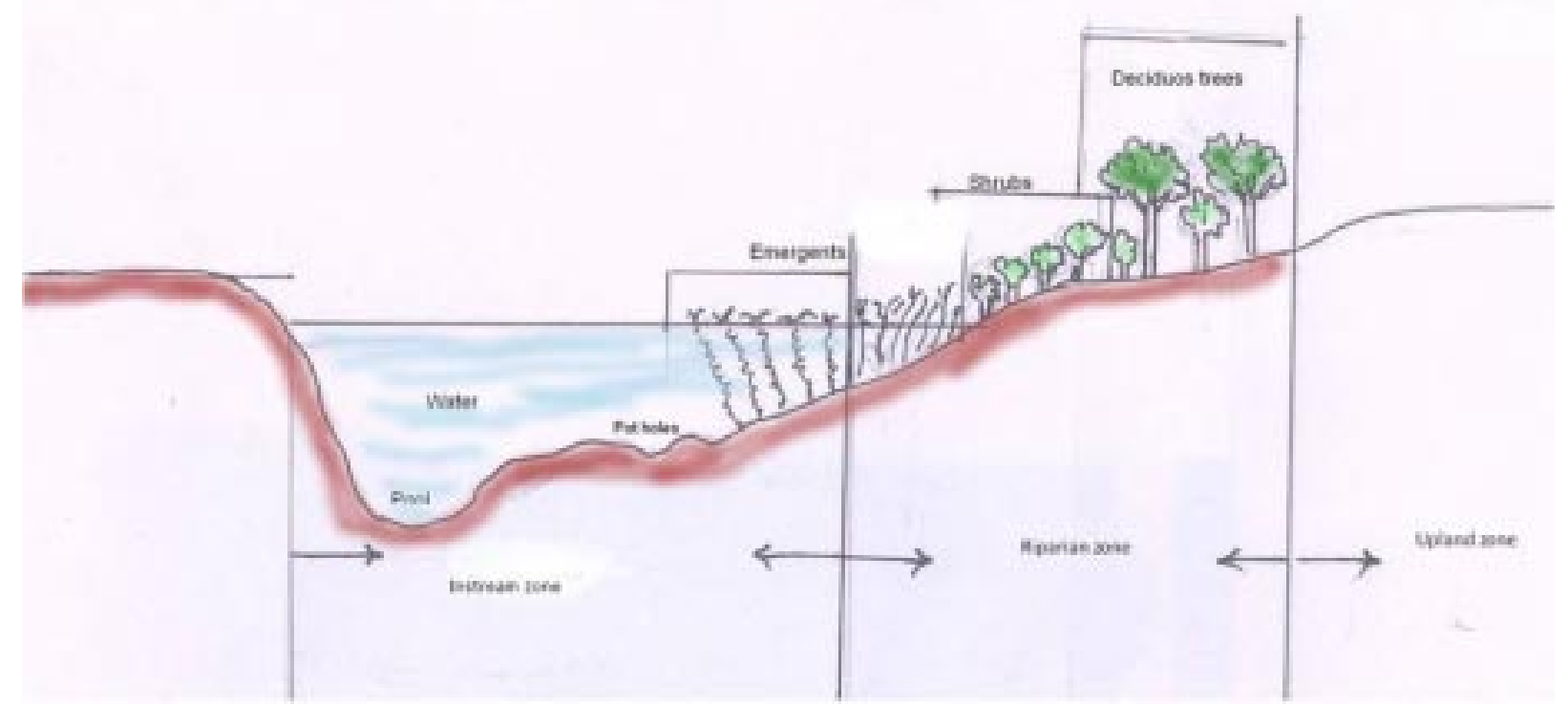

Fig. 4 : Distribution of plant types according to habitats

physical features such as, exposed rocky surfaces in the stream bed, alluvial filled surfaces on the banks, potholes, sandy surfaces on the river bed and boulder piles, etc. These riverine features are habitats for various kinds of organisms like plants, animals and microbial organisms. Oxygenation of river water takes place when it flows over exposed rocky surfaces. Several years of alluvial deposition creates riparian zones. These zones perform important functions like nutrient cycling, absorbing and releasing flood waters, maintaining fish and wildlife habitats. The riparian zone is a series of aquatic and terrestrial vegetation bands or eco tones through which matter and water exchange takes place. Similarly, habitats like grassy patches, potholes, sand flats etc. play important role in biological functions. The biotic component of the river filters contaminants in the flow. We recommend:

i. Creation of in-stream habitats such as pile of boulders in the streams, creation of sand flats, conservation of potholes and creation of riparian zone by plantation

ii. Protection of existing riparian vegetation zone.

\section{Construction activities}

It is important that utmost care be taken to conserve the ecosystem along with its habitats, during the construction of any interventions as a part of the Riverfront Project. During any construction of the Riverfront Project, the following guidelines can be followed. i. The natural topography and drainage patterns of the river, riverbanks and riverbed must be conserved during construction.

ii. The natural proportion of hardscape (impervious cover) and softscape (soil, natural vegetation) must be maintained during construction. Adequate provision of recharge or discharge areas of aquifers must be kept at the time of planning of any development work.

iii. Use of natural materials such as stone, mud, mud bricks, lime, local species of timber and bamboo must be encouraged for construction activity. Use of cement should be kept to a minimum.

iv. Care must be taken that surrounding natural physical features, habitats and biodiversity is not disturbed during the construction process. Earth moving machines cause large scale destruction of habitats and are best avoided around the hotspots. Manual labor must be given priority over these machines when possible.

v. Material like mud, silt, stone and sand shall not be procured from the riverbed, banks, alluvial terraces or upland zones adjoining the river.

vi. Vehicular circulation for carrying the construction materials to the site must be planned and demarcated before commencement of the construction activity.

\section{Water Quality}

Presently, there is more sewage than fresh water in 
the river. We suggest the following measures:

i. No untreated sewage must be added to the river. It is critical that adequate STPs, be installed for the growing population. However, just having STPs is not enough. They have to be fully functional, treated as critical infrastructure, and also up to the latest global standards, as applicable to India. They must be monitored

ii. STPs are not a long-term sustainable solution as they are unable to treat all pollutants. It is important to execute alternate sewage management systems such as bio-remediation. Another additional way to treat sewage is to reconstruct and revive instream habitats by restoration methods. A pilot testing is recommended before any large-scale implementation.

iii. All construction debris dumped within the red and blue flood lines to be immediately removed. This adds to the pollution and is a flood safety hazard.

iv. All encroachment within the red and blue flood lines to be demolished. This is hazardous for functioning of river ecosystem and even risk of flooding in the encroached area.

v. All the access points from which solid waste dumping happens into the river to be identified and mapped and appropriate design/planning solutions to be suggested to prevent the same.

vi. Water quality of the river must be maintained as per international/tropical standards i.e. D.O. should be 8PPM (parts per million).

vii. Non-toxic and natural alternatives to chemical domestic products such as soaps, shampoos, detergents to be identified and promoted by the Pune Municipal Corporation.

\section{Channelization}

The channelization restricts the free flow by confining it to channelized area of river and its feeding streams. The rest of the channel bed then remains dry and it affects adversely for aquatic flora and fauna. Therefore it is essential to remove the channelization. After removal of the channelization, following monsoon cycle should be studied to ascertain the natural character of the river before finalizing the Riverfront Development Plan.

\section{Aquifers and Hydrology}

The hydrology of the urban part of the Mula-Mutha River has undergone massive changes due to number of interventions in the channel and on the banks.

i. It is advised that identification and mapping of aquifers and its recharge areas is essential to enhance ground water recharge. While designing riverfront, hardscaping of the recharge areas must be avoided. These areas should be preserved and protected without any interventions. Natural vegetation on the banks should be preserved for the recharge of ground water.

ii. Natural springs in the catchment must be conserved as it adds fresh water to the river flow.

iii. Feeding streams used to flow naturally and recharging adjacent aquifers. The open space along these feeding streams which was essential for recharging of aquifers is now encroached upon by adjacent housing colonies. These feeding streams have been channelized, narrowed and concretized and look like a canal. Because of this feeding streams have lost their ecological role. So it is necessary to re-establish its natural character again.

\section{Environmental flow}

There is a directive by Supreme Court of India regarding environmental flow of rivers which is cited as follows :

"In NGT ruling of Pusha Saini vs. Ministry of Environment, Forest \& Climate Change \& Ors., about the Environmental flow of all rivers in India, the Court says "...we direct that all the rivers in the Country shall maintain minimum $15 \%$ to $20 \%$ of the average lean season flow of that river. However, whichever State is unable to adhere to this average percentage, in that event we grant liberty to that State Government to move the Secretary, Ministry of Environment, Forest and Climate Change (MoEFCC) who shall in consultation with the Ministry of Water Resources examine such a representation and if it is desirable to fix any lower percentage than the percentage foretasted, then it will pass appropriate order. The order should be reasoned and thereafter it would be left to the discretion of the State concerned to follow the directions of the Ministry in accordance with law. We also grant liberty to the Applicant to move MoEFCC if it has material with them in respect of any river of the country, which should have minimum environment flow in excess of $20 \%$. If such representation is moved the same shall be disposed of by the Committee headed by Secretary in the Ministry of Environment, Forest and Climate Change in accordance with law." (See annexture)

Based on this ruling by the NGT, we recommend that minimum E-flow of $15 \%$ to $20 \%$ of the total flow must be released in the Mula-Mutha Rivers. To decide actual quantity of e-flow, a detailed study is required. 


\section{Geology}

i. Geologically important areas such as alluvial filled surfaces are worth preserving at least at one or two places e. $g$ on the river bank near Mhatre Bridge. These places are important from the applied research point of view. Deposited alluvium can throw light on the paleo- climate and based on the study these sediments can aid in scientific prediction of future climate.

ii. Special geological features like spring, if identified in and along the course of the river, its preservation will be useful for conducted educational river walks and had enormous community value.

\section{Guidelines for creating facilities for citizens and activities around the river}

It is important to provide facilities and activities to fulfill citizen's daily needs. However, such facilities and activities should be allowed only at appropriate places and in a managed way.

The reason for this is an intrinsic limit to the types of facilities and their scale that a river ecosystem can sustain. Conservation of Ghats and historical monuments, gardens is also essential and its design should be complementary to nature.

\section{Grazing}

Presently cattle in large numbers graze along the river flow. Such large scale, round-the-year grazing is detrimental to the riverine ecosystem as well as aesthetic value of the river. It is therefore necessary to assign fixed location for grazing and animal shade.

\section{Fishing}

i. Fishing should be permitted only after water quality and habitats are restored.

ii. Devise a permit system to regulate fishing activity. This will prevent the over exploitation of fish.

iii. No large nets, motorboats or hi-tech equipment shall be allowed for fishing.

iv. No fishing should be allowed in the breeding periods of fish.

v. Hotspots like rocky banks and mudflats that act as spawning areas must be protected from fishing.

\section{Dhobi Ghats (washing clothes on a business scale)}

i. Dhobi ghats should be retained in the Riverfront development Project.

ii. Dhobi ghat facilities should be at fixed locations but away from the main stream and limited in numbers. iii. The discharge water from such activities should be treated.

iv. Chemical detergents should not be used in washing; instead Environmental-friendly alternatives should be used.

\section{Vehicle washing}

Vehicle washing should be only allowed at assigned locations and with proper design.

\section{Rituals}

There are two rituals which are related to river water. One daily organic waste created by performing pooja is throne in the river water. Another event is of Gnapati idol immersion. For these rituals alternatives should be provided by PMC with proper publicity.

\section{Eateries}

Currently there are many eating places and shacks along the river. Such eateries contribute significantly to water pollution in the river. Instead, carefully planned and designed eating place facility is required. Area for eateries must be restricted. It cannot be in the physical proximity of the river. A ban should be in place and enforced on plastic bags, containers, disposable cutlery in eateries around the river.

\section{Recreation}

i. The river provides recreational facilities to citizens. The river is calm with a cool breeze. The beauty of the natural river is a source of joy for the citizen. To add this visual beauty, a series of gardens can be created along the rivers.

ii. Among the recreation areas around the river, some are in tune with the serene character of the river. Circus should not be allowed in the riverbed.

iii. The riverbed should not be altered for boating or any water sports.

iv. No pollutants of any kind should be released through any recreational activity.

\section{Heritage}

i. The Heritage structures along the river must be identified monitored, and restored.

ii. A Heritage walk connecting these structures along the river can be planned. The objective of this walk is to revive the bond between the people and the river and showcase it's history.

\section{Nature trails - Birds / Insects / Flora walks}

i. Restoration of the river ecosystem will boost the flora and fauna along the river. Thus, trails can be 
planned for studying plants, birds, insects, fishes etc.

ii. Care must be taken to not disturb the hotspots while planning these trails.

\section{Studies and documentation essential before execution of the riverfront development project.}

It is recommended that the following studies be carried out before planning and execution of Riverfront Development / River Rejuvenation project:

i. Aquifer mapping

ii. Biodiversity assessment

iii. Habitat mapping

iv. Identifying Old growth trees, Riparian zone mapping

v. Water quality assessment

vi. Feeding Stream mapping

vii. Drainage and topography studies

\section{Flood control and encroachments}

i. In the survey it was observed that demarcated red and blue flood lines near Waraje Bridge appear to be incorrect as they are very closely spaced. In this view, it is suggested that verification of the red and blue flood lines be undertaken.

ii. It is observed during the survey that settlements and roads are within the Red and blue line. (e.g.Location near Vithalmandir at Vithalwadi) we recommend that all encroachments within the red flood line be removed.

iii. Safety measures considering a worst-case scenario of structural damage or breakage of the three upstream dams must be considered for the same.

iv. There is an immediate need to formulate a policy to stop development on the banks of the rivers. These banks must be kept reserved for the development of riparian habitat.

v. All illegal construction and debris dumped within the red and blue flood lines must be removed.

vi. It is suggested that new retention basins should be created wherever space is available. These are useful to manage storm water runoff. It also helps in preventing over bank flooding and downstream erosion. These are commonly used in other countries and called as wet pond or wet detention basins or storm water management pond. It is an artificial lake with vegetation around the perimeter and includes a permanent pool of water in its design. These pools have wetland ecosystem value and they become complimentary to the river ecosystem.

Therefore, we recommend the creation of retention / detention basins along the river wherever sufficient space is available. An expert must be consulted for this.

\section{Upstream and Downstream policies}

i. The river is a continuum. The MuthaRiver, flowing through Pune city, has originated in the Western Ghats. What happens in the catchment area of the origin affects the river stretch in Pune city. For example, solid waste dumping in Kirkitwadi stream adds to the pollution to the river. Similarly, the happenings in Pune city will affect river corridor in the downstream area. For example, the polluted water of the city will be delivered to the downstream villages and towns. Therefore the river policy must consider the upstream and downstream effects. While formulating the policy, we recommend the Payment for Ecosystem Services (PES) Model can be adopted. This is described in detail on the UNDP website. The collection from this should be used for conservation and restoration of ecologically important areas upstream of the city, especially around the source of the Mula and Mutha rivers.

ii. Polluter pays principle may be also applied in case of bad water quality downstream. This fund may be used for water quality improvement and river restoration downstream.

\section{Wind corridor}

River provides an important service of temperature regulation. It acts as a wind corridor allowing a continuous passage of air. This passage helps in regulating temperature of the surrounding area. Considering specific case of Mutha River - "Fortunately, the Mutha River flows from west to east through the city and provides a corridor for fresh air that blows from hills to the west and south-west. Through these corridors the fresh and cool winds enter the densely populated areas much to the relief of the residents.

Tall buildings along the riverfront interfere with the free flow of fresh air. Also, broad roads while they may relieve the traffic congestion in some parts may give rise to air pollution if heavy vehicular traffic is allowed on such roads. The fumes generated by the vehicles will be blown into city's congested areas by the winds blowing from the west and further foul the atmosphere there. It is therefore, advisable to avoid heavy traffic on roads proposed to be built at the edge of the river basin and allow the winds to flow freely." (Survey of the rivers in Pune city, based on ecological factors in order to prepare an eco-development plan to improve the river-fronts of Pune, Swati Gole) 
We strongly recommend that the policy level development control regulations must be framed along the riverbanks to protect this ecological function of the river.

\section{Maintenance}

i. Before the Riverfront Development project is commenced, it is of prime importance to propose a plan for its maintenance.

ii. A fund to be set up for the maintenance and upkeep of the project and the recommendations in this report.

iii. Involvement of local communities and other stakeholders must be encouraged in the maintenance of project, and conservation of hotspots.

\section{Compensation}

In case of any proposal that can potentially damage the ecosystem, its habitats, flora, fauna, aquifer recharge and discharge zones, the work shall not commence before an appropriate compensation of the ecological features or services are provided.

\section{Recommendations for design interventions}

The proposed design for riverfront development by PMC shows excess of hard scape on both channel floor and the banks. Therefore, this study suggests ecologically sound alternative designs.

\section{Maintaining a balance between built interventions vs restoration / conservation}

An ecologically sensitive approach to Riverfront
Development of the Mula-MuthaRiver must have the right balance between the built interventions and stretches where the river has retained its natural course. It is important to have a physical connect between the city and the river. However, one must also consider that restoring the natural ecological functions and services of the river ecosystem will also contribute to and complement the built interventions. The modern view of site development is to create a design where prime focus on inclusion of natural entities, its preservation and conservation.

The Fig. 5 schematically illustrates the difference between the straitened river course like a canal and natural sinuous form of the river. Sinuous river course is beneficial to hydrology, especially during floods. Significant quantities flood water is contained in the channel, reducing scale of the flood. It is also beneficial to riverine organisms and aesthetically more appropriate.

\section{Policy regarding access points}

In the design of PMC access to river for citizens is shown all along the riverfront.To reduce stresses and managing riverfront in better manner shown in Fig. 6, it is suggested that to have limited access where control will be easy. It will also help reduce pollution and disturbance of important habitats.

This will enhance the water quality as well as aesthetic appeal of the interventions defined as a part of the Riverfront Development Project.

We do not suggest raising barriers and depriving the citizens of the space. Barrier designs must allow a

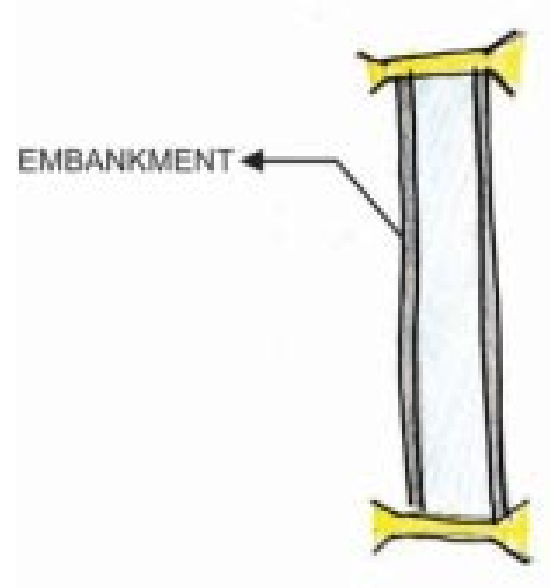

A. proposed Chanelisation

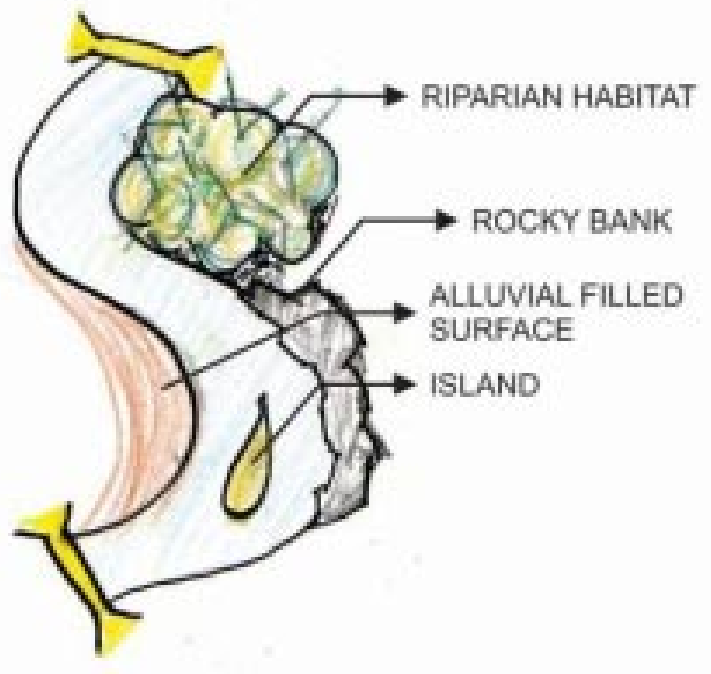

B. suggested Natural course

Fig. 5 


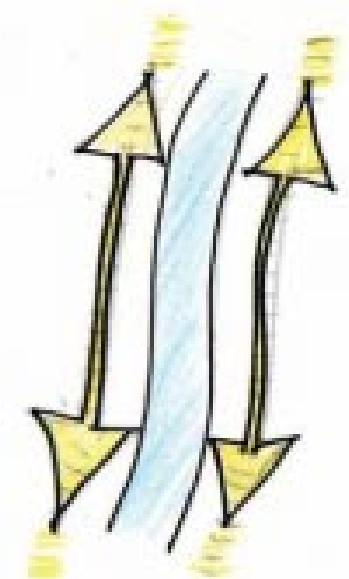

A. Proposed continuous access

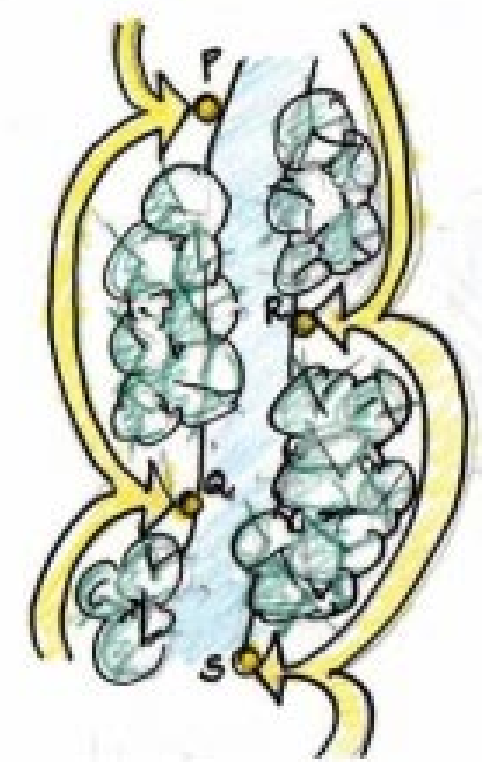

B. Suggested limited access

Fig. 6

visual access to the river and its banks as shown in Fig. 7. For example, when a jogging track is to be provided for some distance, parallel to the river, it can be a raised walkway that provides a continuous view of the river but causes minimum disturbance to the habitat shown in Fig. 9.

\section{Protection of natural patches by creating tall visual} barriers verses access barriers ensuring visual connectivity
In the above illustration, the access restriction need not be with tall barriers as shown on the left. This can be achieved through natural hedges, level differences or raised pathways.

4. Creating stepping stones and Integrating open spaces along the river

A single huge natural space can accommodate greater biodiversity and will be more stable. However,

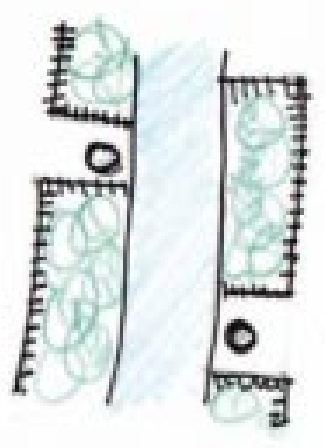

A Proposed barrier design

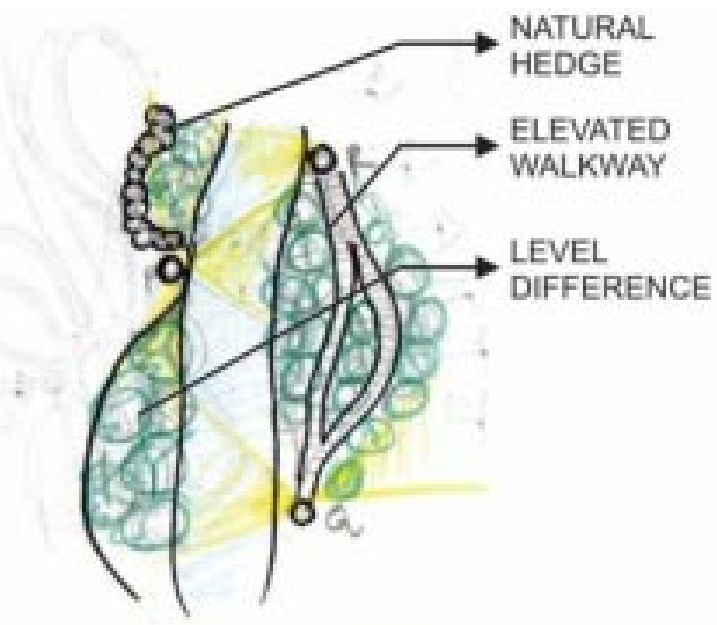

B. suggested barrier design

Fig. 7 


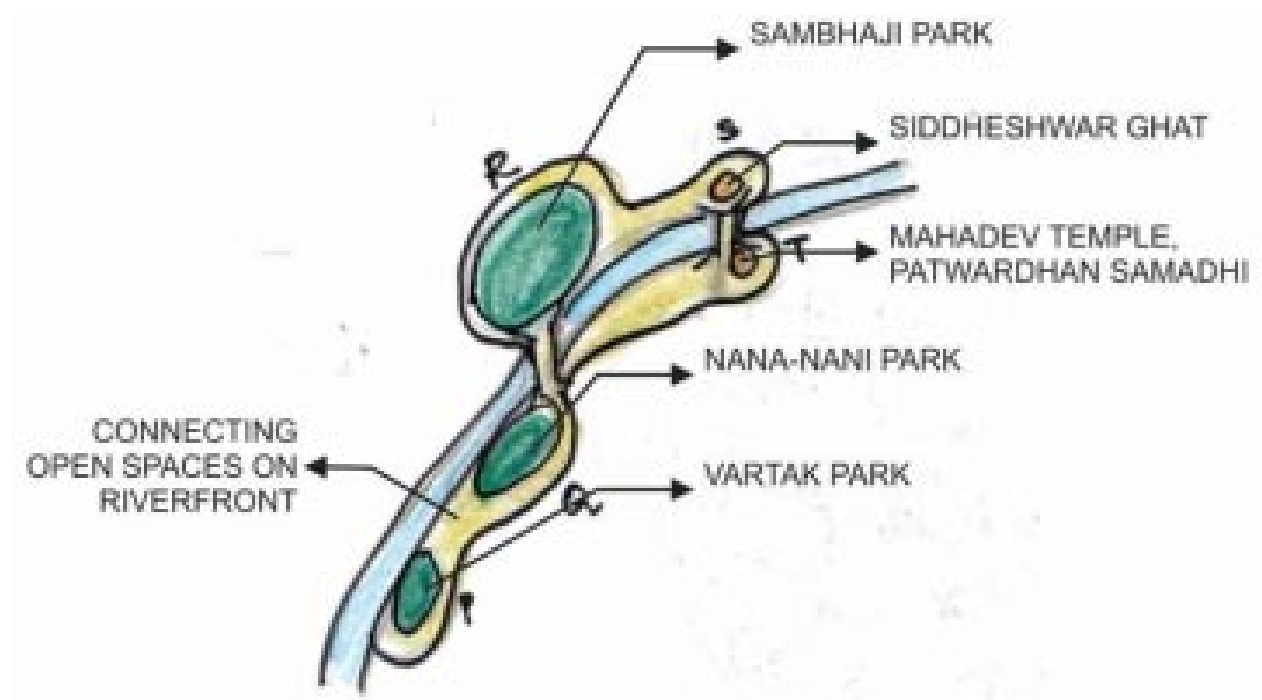

Fig. 8: Suggested design for Integrating existing open spaces into a single riparian theme

it is extremely hard to have continuous large natural areas in the cities. The small patches of wilderness can act as an island or stepping stones for organisms. Creation of such steppingstones is a known and experimented solution to strengthen urban biodiversity. Another suggestion is to create a large size natural open space for stability of the ecosystem. The good example will be of connecting several existing such small gardens along the river can be created as shown in the Fig. 9.

While connecting these open spaces to form one single open space, it is essential to develop a Riparian habitat themed garden. This way, it will also add to the ecological quality to this river stretch.

\section{Effective planning of vehicular circulation}

It is important to plan the circulation of vehicles, pedestrians, cyclists effectively in the riverfront design. A limited number of entry and exit points must be provided to the riverfront to minimize the habitat degradation and reduce pollution. Similarly, effective design measures must be employed to disallow solid waste dumping from bridges / causeways.

Instead of planning a linear pathway along the

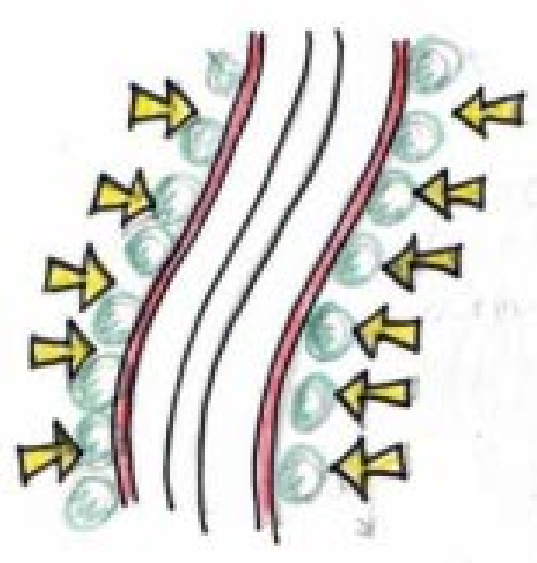

A. Proposed access along the entire stretch

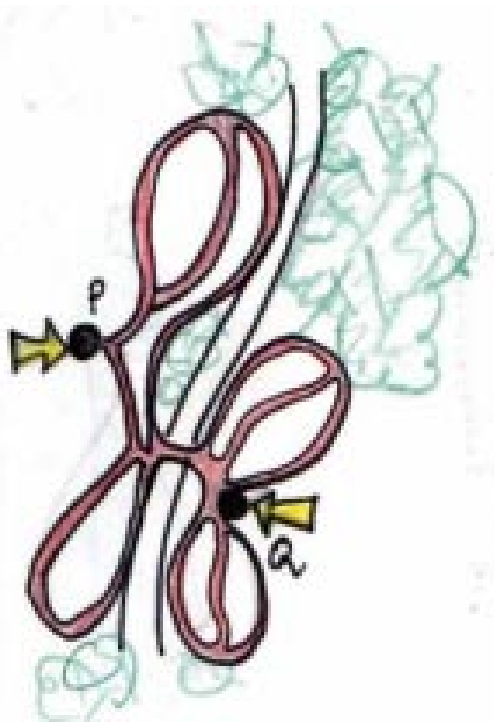

B. Suggested access at limited points

Fig. 9 
river, the same length of pathway can be designed to control entry and exit points, as shown in Fig. 9. This will reduce the pollution along the riverbanks and channel. For example, figure A, shows continuous access and figure B shows controlled points. Car parking can be planned only at such limited entry / exit points.

\section{Specific recommendations for each zone}

The biodiversity survey outcome of each zone was mapped and the interventions praposed by PMC were considered to suggest interventions and specific management plan for each zone.Below is the example of zone 1.1 and 1.2

For zone No. 1.1 a partial Intervention strategy is recommended. The various patches in this zone need specific management.

1. Patch 1 This is the mouth of a feeder stream that meets the river on the left bank. The slope to the left is a gradual one, and there is a lot of area available around the mouth of this nala. Moreover, the flow velocity of the stream being slow, developing a Nala park (Osho park, in Koregaon Park) in this area will be the most effective design strategy.

2. Patch 2 This is the stretch wherein a road was constructed illegally. After the NGT verdict, the work of removing the construction material that was dumped for the road is currently in progress.
However, due to the constant movement of heavy earth moving vehicles in this patch, the natural ecosystem is damaged to a large extent. Thus, substantial intervention in terms of habitat creation, plantation and maintenance is required here. Naturally, alluvial field deposits may have been located here. Thus, efforts must be made to restore this type of ecosystem here.

3. Patch 3 and Patch 6 These patches comprise largely of rocky banks. However, the water no longer reaches these rocks due to the concrete channels constructed in the river bed. These channels must be removed, and the changes must be observed for one seasonal cycle. Accordingly, assisted recovery of habitats in this rocky patch must be attempted.

4. Point 4 This is an access point, used as a dhobi ghat. While water from the river is not actually used for washing clothes, it was observed that the wastewater from washing goes directly into the river. Also, the rocks are used to dry clothes. It is important to retain this activity, as it shows a connect of the people to the river, in their daily routine. However, the activity must be restructured so that the river pollution is prevented. Natural detergents such as Ritha must be encouraged and ones having chemical pollutants must be banned at this spot. Also, the wastewater may be passed through root zone filter beds before

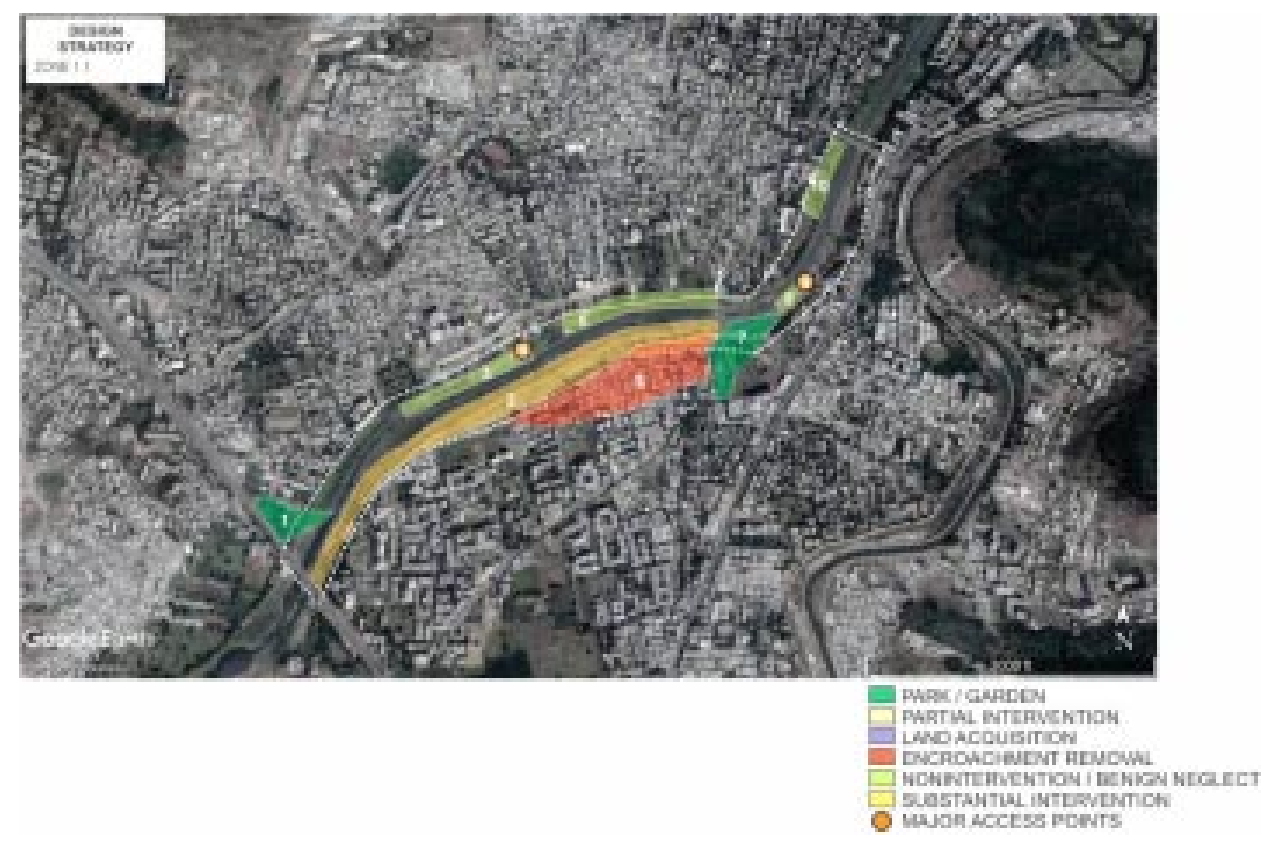

Google Map 3 : A. Zone 1.1 
being let out into the river.

5. Patch 5 One can see numerous structures built within the red and blue flood lines here. It is important for the sake of safety, river ecology as well as law enforcement that these be removed urgently.

6. Patch 7 This is the mouth of a nala that joins the right bank of the river, before Vitthalwadi. It emerges from a settlement nearby and passes under a bridge before joining the river. The area between the nala and the settlement is already cordoned off. Thus, it will be easy to develop like a Nala Park here that will be responsible for a decentralized treatment of the water entering the river. It will also act as a usable open space / garden area for the settlement.

7. Patch 8 This is a rocky patch adjoining the Mahadev temple at Vitthalwadi. It contains nascent stages of potholes. Also, once the channels are demolished, the rocky habitats should be observed, developed and conserved.

8. Point 9 Access point 9 is the Mahadev temple at Vitthalwadi. It experiences peak rush during Ekadashi and Ganpati visarjan. It is essential to control the stress on the rocky habitats nearby during these festivals. Also, circulation must be planned such that there is no disturbance to the hotspots nearby.

9. Patch 10 This is a patch in front of the crematorium in Vitthalwadi. Once the access is restricted, it will be an ideal location for developing Riparian vegetation.

In case of zone No. 1.2 strategy can be as follows :

1. Patches 1,2 and 5 these patches include grassy as well as marshy vegetation. However, one can observe stresses due to illegal dumping of solid waste and debris from the wedding lawns located in the upland zone.

2. Patch 3 This is a marshy patch that is a good habitat for birds, due to absence of channelization. This patch must be protected in its natural state.

3. Patch 4 This is the mouth of a nala, which is actually the discharge from the Parvati water treatment plant. One can observe that a sizeable amount of water is carried into the river, with great velocity here. The nala and the area around it is cordoned off with a fence. It is ideal to make a stroll garden themed Nala Park.

4. Point 6 This is the Dattawadivisarjan Ghat. Clothes and utensil washing activity takes place

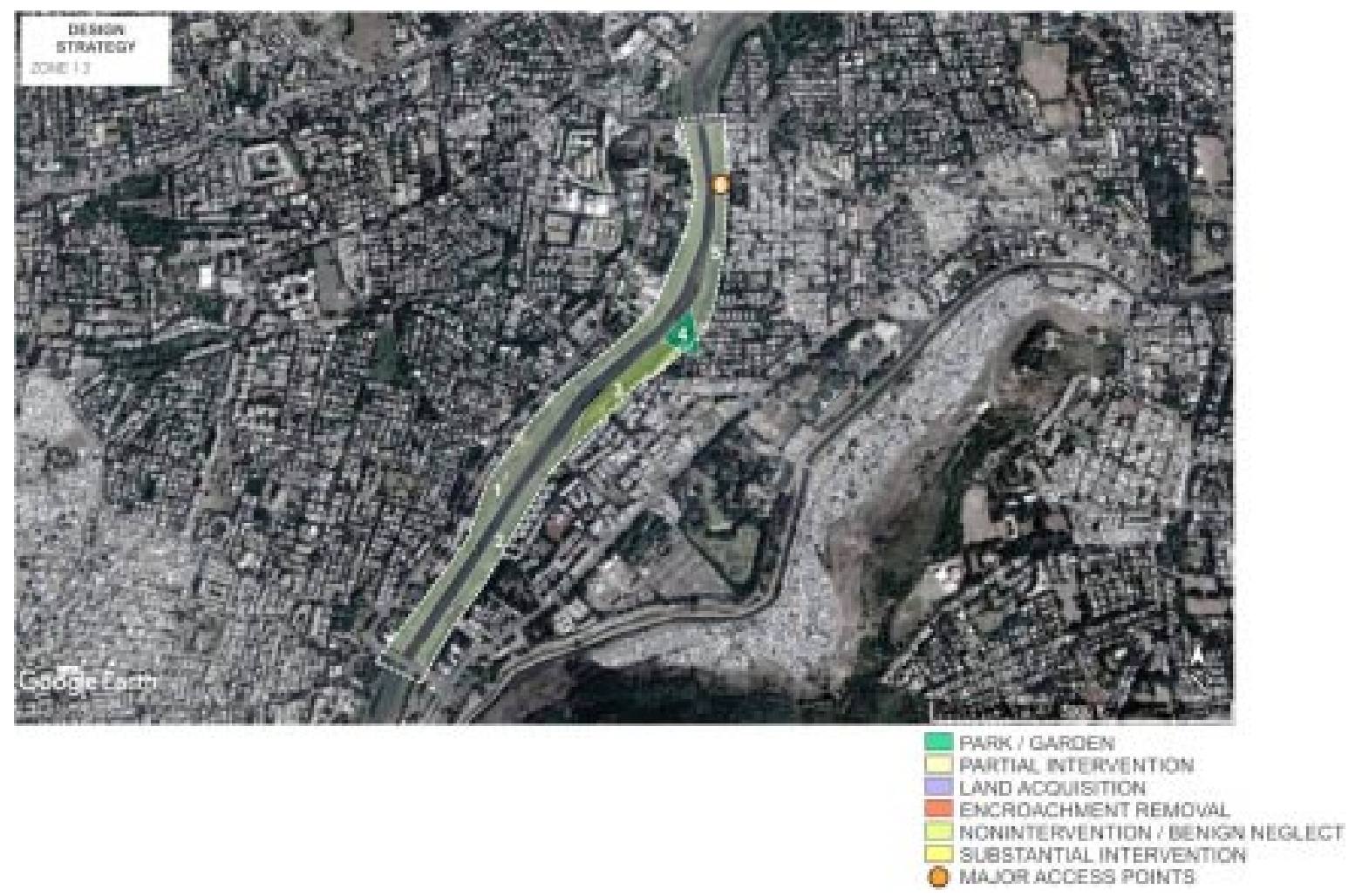

Google Map 4 : B. Zone 1.2 
here in the morning. It can be treated the same way like Point 4 in Zone 1.1. Access must be limited to the ghat itself, and people as well as cattle must not be allowed to roam from the ghat to the adjacent patches 5 and 3 .

\section{General recommendations on what to avoid}

1. No channelization of the river. This is a wellstudied aspect of river ecosystems and there are ample references which support the free flow of river in its own channel. This is clearly the most important DON'T for Mula-Mutha.

2. No concrete / tar / paver block or roads on any of the river banks, streams, riparian zones and springs. They must be retained in their natural state. This retains the character of the river and makes it look like a river and not a canal.

3. No high-rise buildings on the banks. This is to allow an unrestricted view of the river. Within a bustling city, a natural river has the potential to be a place of natural beauty. This must be preserved at all times. As there are hardly any open spaces left for Pune citizen, this is a good opportunity.

4. No eateries/ restaurants / take-aways on the banks and in the river bed. We have identified these as a significant source of pollution and intervention to the natural processes on the banks. Moreover, the eateries today are in the zone where riparian vegetation is possible to be nurtured.

5. Do not use excessive lighting in the river bed. No flood lights or any other forms of excessively bright lights. This is detrimental to insects and nocturnal fauna. We recommend a separate study of lighting for the river zone.

6. No construction / structure in any of the identified ecologically important hotspots. This is critical to the restoration of flora and fauna in the river ecosystem. We have identified many stretches where riverfront development structures can be made.

7. Do not use any non-native species of vegetation for any kind of plantation in the river bed and on its banks. All plantations must only be of native species, relevant to this region of the country and habitat. We have provided a list of such vegetation.

8. Do not allow any untreated water or sewage to enter the river. This is critically important when we are trying to revive aquatic life.

9. Do not allow activities like large gatherings, weddings, circus, exhibitions, political rallies, Dandiya, etc. in the river bed (Refer to the NGT ruling in the case of Art of Living World Culture festival case).

\section{Conclusion}

The city of Pune is blessed with two rivers flowing within it and their confluence. In this age where cities are turning similar with undifferentiated architectural structures, it is critical to preserve a naturally endowed character of the city. A well-maintained river is not just a source of charm for its citizen, but also a provider of vital environmental services that every city needs for healthy functioning. It is this aspect of the river that we strongly recommend being conserved and nurtured, in the riverfront development project. Our recommendations are prioritized on ecological and cultural aspects and employ a holistic perspective of looking at the river as a continuum and a living ecosystem. We are aware that this report has limitations, but we hope that the project designers and planners will find the guidelines worthy of consideration. We would be glad to initiate further discussions to the stakeholders.

"Design needs to shift from a paradigm of transforming nature to one of transforming society; by improving the quality of life and relationships between all living things and the built environment" Prakash Gole, Understanding Reality. 
Full Check-list of Flora of Mula-Mutha

Plant Checklist OF Mula-Mutha River

\begin{tabular}{|c|c|c|c|c|}
\hline \multicolumn{5}{|c|}{ Trees } \\
\hline No. & Scientific Names & Common Name & Family & Occurrence \\
\hline 1 & Acacia auriculiformis Benth. & Australian Babhul & Leguminosae & Occasional \\
\hline 2 & Acacia chundra (Rottler) Willd. & Khair & Leguminosae & Occasional \\
\hline 3 & Acacia nilotica (L.) Delile & Babhul & Leguminosae & Common \\
\hline 4 & Acacia polyacantha Willd. & Pandhra Khair & Leguminosae & Occasional \\
\hline 5 & Adansonia digitata $L$. & Baobab & Malvaceae & Occasional \\
\hline 6 & Aegle marmelos (L.) Corrêa & Bel & Rutaceae & Occasional \\
\hline 7 & Ailanthus excelsa Roxb. & Maharukh & Simaroubaceae & Rare \\
\hline 8 & Albizia lebbeck (L.) Benth. & Shirish & Leguminosae & Occasional \\
\hline 9 & Albizia saman (Jacq.) Merr. & Rain tree & Leguminosae & Occasional \\
\hline 10 & Alstonia scholaris (L.) R.Br. & Satvin & Apocynaceae & Common \\
\hline 11 & Annona squamosa $L$ & Sitaphal & Annonaceae & Occasional \\
\hline 12 & Azadirachta indica A.Juss. & Kadunimb & Meliaceae & Occasional \\
\hline 13 & Bauhinia purpurea L. & Kanchan & Leguminosae & Occasional \\
\hline 14 & Bombax ceiba $L$. & Katesawar & Malvaceae & Occasional \\
\hline 15 & Broussonetia papyrifera (L.) Vent & Paper Mulberry & Moraceae & Common \\
\hline 16 & Capparris grandis L.f. & Pachunda & Capparaceae & Occasional \\
\hline 17 & Carica papaya $L$. & Papai & Caricaceae & Occasional \\
\hline 18 & Cocos nucifera L. & Naral & Arecaceae & Occasional \\
\hline 19 & Cordia dichotoma G.Forst. & Bhokar & Boraginaceae & Occasional \\
\hline 20 & Couroupita guianensis Aubl. & Kailaspati & Lecythidaceae & Occasional \\
\hline 21 & Dalbergia sissoo DC. & Shisav & Leguminosae & Common \\
\hline 22 & Delonix regia (Hook.) Raf. & Gulmohor & Leguminosae & Occasional \\
\hline 23 & Eucalyptus globulus Labill. & Nilgiri & Myrtaceae & Common \\
\hline 24 & Ficus benghalensis L. & Wad & Moraceae & Occasional \\
\hline 25 & Ficus hispida L.f. & Dhedumbar & Moraceae & Occasional \\
\hline 26 & Ficus racemosa $L$. & Umbar & Moraceae & Occasional \\
\hline 27 & Ficus religiosa $L$. & Pimpal & Moraceae & Occasional \\
\hline 28 & Gliricidia sepium (Jacq.) Walp. & Undirmari & Leguminosae & Common \\
\hline 29 & Gmelina arborea Roxb. & Shivan & Lamiaceae & Occasional \\
\hline 30 & Grewia tiliifolia Vahl & Dhaman & Malvaceae & Occasional \\
\hline
\end{tabular}




\begin{tabular}{|c|c|c|c|c|}
\hline No. & Scientific Names & Common Name & Family & Occurrence \\
\hline 31 & Holoptelea integrifolia Planch. & Waval & Ulmaceae & Occasional \\
\hline 32 & Leucaena leucocephala (Lam.) de Wit & Subabhul & Leguminosae & Common \\
\hline 33 & Limonia acidissima Groff & Kavath & Rutaceae & Occasional \\
\hline 34 & Mangifera indica $L$ & Amba & Anacardiaceae & Occasional \\
\hline 35 & Millingtonia hortensis L.fil. & Booch & Bignoniaceae & Common \\
\hline 36 & Mimusops elengi L. & Bakul & Sapotaceae & Occasional \\
\hline 37 & Morinda pubescens Sm. & Bartondi & Rubiaceae & Occasional \\
\hline 38 & Moringa oleifera Lam. & Shewaga & Moringaceae & Occasional \\
\hline 39 & Muntingia calabura L. & Singapore cherry & Muntingiaceae & Occasional \\
\hline 40 & Neolamarckia cadamba (Roxb.) Bosser & Kadamb & Rubiaceae & Occasional \\
\hline 41 & Peltoforum pterocarpum Auct. non K.Heyne & Tambadsheng & Leguminosae & Common \\
\hline 42 & Phoenix sylvestris (L.) Roxb. & Shindi & Arecaceae & Occasional \\
\hline 43 & Pithecellobium dulce (Roxb.)Benth. & Vilayati Chinch & Leguminosae & Common \\
\hline 44 & Polyalthia longifolia (Sonn.) Thwaites & Ashok & Annonaceae & Common \\
\hline 45 & Pongamia pinnata (L.) Pierre & Karanj & Leguminosae & Occasional \\
\hline 46 & Prosopis juliflora (Sw.) DC & Wedi babhul & Leguminosae & Common \\
\hline 47 & Psidium guajava L. & Peru & Myrtaceae & Occasional \\
\hline 48 & Pterospermum acerifolium (L.) Willd. & Muchkund & Malvaceae & Occasional \\
\hline 49 & Putranjiva roxburghii Wall. & Putranjiva & Putranjivaceae & Occasional \\
\hline 50 & Salix tetrasperma Roxb. & Walunj & Salicaceae & Rare \\
\hline 51 & Santalum album L. & Chandan & Santalaceae & Occasional \\
\hline 52 & Senna siamea (Lam.) H.S.IrwinE Barneby & Kashid & Leguminosae & Occasional \\
\hline 53 & Solanum nigrum L. & & Solanaceae & Occasional \\
\hline 54 & Spathodea campanulata Beauv & Pichkari & Bignoniaceae & Common \\
\hline 55 & Spathodea campanulata P.Beauv. & Pichkari & Bignoniaceae & Occasional \\
\hline 56 & Sterculia foetida $L$. & Punai & Malvaceae & Occasional \\
\hline 57 & Syzygium cumini (L.) Skeels & Jambhul & Myrtaceae & Occasional \\
\hline 58 & Syzygium heyneanum (Duthie)Wall.ex Gamble & Panjambhul & Myrtaceae & Rare \\
\hline 59 & Tamarindus indica L. & Chinch & Leguminosae & Occasional \\
\hline 60 & Terminalia arjuna (Roxb. ex DC.) Wight E Arn. & Arjun & Combretaceae & Occasional \\
\hline 61 & Terminalia catappa L. & Badam & Combretaceae & Occasional \\
\hline 62 & Terminalia cuneata Roth & Arjun & Combretaceae & Occasional \\
\hline 63 & Trema orientalis (L.) Blume & Ghol & Cannabaceae & Occasional \\
\hline
\end{tabular}




\begin{tabular}{|c|c|c|c|c|}
\hline No. & Scientific Names & Common Name & Family & Occurrence \\
\hline 64 & Zizipus mauritiana Lamk. & Bor & Rhamnaceae & Occasional \\
\hline \multicolumn{5}{|c|}{ Herbs } \\
\hline 1 & Abutilon indicum (L.) Sweet & Mudra & Malvaceae & Common \\
\hline 2 & Acalypha ciliata Forssk. & & Euphorbiaceae & Common \\
\hline 3 & Achyranthes aspera $L$. & Aaghada & Amaranthaceae & Common \\
\hline 4 & Aeschynomene indica $L$. & & Leguminosae & Common \\
\hline 5 & Ageratum conyzoides (L.) L. & & Compositae & Common \\
\hline 6 & Alternanthera philoxeroides (Mart.) Griseb. & Alligator weed & Amaranthaceae & Abundant \\
\hline 7 & Alternanthera pungens Kunth & & Amaranthaceae & Occasional \\
\hline 8 & Alternanthera sessilis (L.) R.Br.ex DC. & Chabuk kata & Amaranthaceae & Abundant \\
\hline 9 & Alysicarpus tetragonolobus Edgew. & & Leguminosae & Occasional \\
\hline 10 & Amaranthus spinosus L. & Katemath & Amaranthaceae & Common \\
\hline 11 & Amaranthus viridis $L$. & Math & Amaranthaceae & Common \\
\hline 12 & Ammannia baccifera L. & & Lythraceae & Rare \\
\hline 13 & Apluda mutica L. & & Poaceae & Common \\
\hline 14 & Argemone mexicana L. & Pivala dhotra & Papaveraceae & Common \\
\hline 15 & Asclepias curassavica L. & Haladi Kunku & Apocynaceae & Common \\
\hline 16 & Azolla pinnata $R . B r$. & & Salviniaceae & Abundant \\
\hline 17 & Bacopa monnieri (L.) Wettst. & Neerbrahmi & Plantaginaceae & Occasional \\
\hline 18 & Bambusa vulgaris Schrad. & Yellow Bamboo & Poaceae & Occasional \\
\hline 19 & Bidens biternata (Lour.) Merr. \& Sherff & & Compositae & Occasional \\
\hline 20 & Boerhavia diffusa $L$. & Punarnava & Nyctaginaceae & Occasional \\
\hline 21 & Brassica juncea (L.) Czern. & Mohori & Brassicaceae & Occasional \\
\hline 22 & Canna indica L. & Kardal & Cannaceae & Occasional \\
\hline 23 & Canscora diffusa (Vahl) R.Br. ex Roem. E Schult. & Kilwar & Gentianaceae & Occasional \\
\hline 24 & Celosia argentea $L$. & Kurdu & Amaranthaceae & Common \\
\hline 25 & Centella asiatica (L.) Urb. & Mandukparni & Apiaceae & Occasional \\
\hline 26 & Chloris virgata Sw. & & Poaceae & Common \\
\hline 27 & Chromolaena odorata (L.) R.M.KingE H.Rob. & Ranmari & Compositae & Abundant \\
\hline 28 & Cleome rutidosperma DC. & & Cleomaceae & Rare \\
\hline 29 & Cleome viscosa L. & Pivali Tilwan & Cleomaceae & Occasional \\
\hline 30 & Colocassia esculenta (L.) Scott & Ran-alu & Araceae & Common \\
\hline 31 & Commelina benghalensis L. & Keni & Commelinaceae & Common \\
\hline
\end{tabular}




\begin{tabular}{|c|c|c|c|c|}
\hline No. & Scientific Names & Common Name & Family & Occurrence \\
\hline 32 & Commelina caroliniana Walter & & Commelinaceae & Common \\
\hline 33 & Corchorus sp. & Chunch & Malvaceae & Common \\
\hline 34 & Cosmos sulphureus Cav. & Cosmos & Compositae & Common \\
\hline 35 & Croton bonplandianus Baill. & & Euphorbiaceae & Occasional \\
\hline 36 & Cullen corylifolium (L.) Medik. & Bavachi & Leguminosae & Common \\
\hline 37 & $\begin{array}{l}\text { Cyanotis fasciculata (B.Heyne ex Roth) } \\
\text { Schult. \& Schult.f. }\end{array}$ & Nilwanti & Commelinaceae & Common \\
\hline 38 & Cyanthillium cinereum (L.) H.Rob. & Sahdevi & Compositae & Common \\
\hline 39 & Cynodon dactylon (L.) Pers. & Harali & Poaceae & Common \\
\hline 40 & Cyperus scariosus R.Br. & Lavhale & Cyperaceae & Occasional \\
\hline 41 & Dactyloctenium aegyptium (L.) Willd. & & Poaceae & Common \\
\hline 42 & Datura innoxia Mill. & Dhotara & Solanaceae & Occasional \\
\hline 43 & Datura metel L. & Dhotara & Solanaceae & Rare \\
\hline 44 & Desmodium tortuosum (Sw.) DC. & & Leguminosae & Common \\
\hline 45 & Digitaria ciliaris (Retz.) Koeler & & Poaceae & Common \\
\hline 46 & Dinebra retroflexa (Vahl) Panz. & & Poaceae & Common \\
\hline 47 & Echinochloa colona (L.) Link & & Poaceae & Common \\
\hline 48 & Eclipta prostrata (L.) L. & Maka & Compositae & Occasional \\
\hline 49 & Eichhornia crassipes (Mart.) Solms & Jalparni & Pontederiaceae & Abundant \\
\hline 50 & Emilia sonchifolia (L.) DC. ex DC. & & Compositae & Occasional \\
\hline 51 & Euphorbia heterophylla L. & Dudhi & Euphorbiaceae & Common \\
\hline 52 & Euphorbia hypericifolia L. & Dudhi & Euphorbiaceae & Common \\
\hline 53 & Exacum pedunculatum L. & & Gentianaceae & Occasional \\
\hline 54 & Glinus lotoides L. & & Molluginaceae & Common \\
\hline 55 & Gomphrena sp. & & Amaranthaceae & Occasional \\
\hline 56 & Grangea maderaspatana (L.) Poir. & Mashpatri & Asteraceae & Common \\
\hline 57 & Gynandropsis pentaphylla (L.) & & Capparaceae & Common \\
\hline 58 & Heliotropium indicum L. & Bhurundi & Boraginaceae & Occasional \\
\hline 59 & Hibiscus sp. & & Malvaceae & Occasional \\
\hline 60 & Hygrophila auriculata (Schumach.) Heine & Talimkhana & Acanthaceae & Abundant \\
\hline 61 & Hyptis suaveolens (L.) Poit. & Darptulas & Lamiaceae & Occasional \\
\hline 62 & Indigofera glandulosa Wendl. & Borpudi & Leguminosae & Rare \\
\hline 63 & Ipomoea aquatica Forssk. & Nalichi Bhaji & Convolvulaceae & Abundant \\
\hline 64 & Lagascea mollis Cav. & & Compositae & Occasional \\
\hline
\end{tabular}




\begin{tabular}{|c|c|c|c|c|}
\hline No. & Scientific Names & Common Name & Family & Occurrence \\
\hline 65 & Launaea procumbens (Roxb.) Ramayya \& Rajagopal & & Compositae & Occasional \\
\hline 66 & Lemna gibba L. & & Araceae & Abundant \\
\hline 67 & Leonotis nepetifolia (L.) R.Br. & Deepmal & Lamiaceae & Occasional \\
\hline 68 & Leucas biflora (Vahl) Sm. & & Lamiaceae & Rare \\
\hline 69 & Leucas longifolia Benth. & & Lamiaceae & Common \\
\hline 70 & Ludwigia octovalvis (Jacq.) P.H.Raven & Panlawang & Onagraceae & Common \\
\hline 71 & Martynia annua L. & Vinchawi & Martyniaceae & Occasional \\
\hline 72 & Mollugo pentaphylla L. & & Molluginaceae & Common \\
\hline 73 & Ocimum gratissimum L. & Tulas & Lamiaceae & Occasional \\
\hline 74 & Oldenlandia corymbosa L. & & Rubiaceae & Common \\
\hline 75 & Oxalis corniculata L. & Amboshi & Oxalidaceae & Common \\
\hline 76 & Parthenium hysterophorus L. & Gajar Gavat & Compositae & Abundant \\
\hline 77 & Persicaria glabra (Willd.) M.Gómez & Sheral & Polygonaceae & Abundant \\
\hline 78 & Phyla nodiflora (L.) Greene & Neerbrahmi & Verbenaceae & Occasional \\
\hline 79 & Phyllanthus niruri L. & Bhuiawali & Phyllanthaceae & Common \\
\hline 80 & Physalis minima $L$. & Popati & Solanaceae & Abundant \\
\hline 81 & Pistia stratiotes $L$. & & Araceae & Occasional \\
\hline 82 & Plumbago zeylanica $L$. & Chitrak & Plumbaginaceae & Occasional \\
\hline 83 & Portulaca oleracea L. & Gholu & Portulacaceae & Common \\
\hline 84 & Ruelia tuberosa L & & Acanthaceae & Occasional \\
\hline 85 & Senna sophera (L.) Roxb. & & Leguminosae & Occasional \\
\hline 86 & Senna tora (L.) Roxb. & Takala & Leguminosae & Abundant \\
\hline 87 & Senna uniflora (Mill.) H.S.Irwine Barneby & & Leguminosae & Abundant \\
\hline 88 & Sesamum orientale L. & Rantil & Pedaliaceae & Occasional \\
\hline 89 & Setaria pumila (Poir.) Roem. \& Schult. & & Poaceae & Common \\
\hline 90 & Sida acuta Burm.f. & Bala & Malvaceae & Occasional \\
\hline 91 & Solanum lycopersicum L. & Tomato & Solanaceae & Occasional \\
\hline 92 & Solanum virginianum $L$. & Katerigani & Solanaceae & Occasional \\
\hline 93 & Spermacoce pusilla Wall. & & Rubiaceae & Common \\
\hline 94 & Spilanthes acmella (L.) L. & & Compositae & Occasional \\
\hline 95 & Spirodela polyrrhiza (L.) Schleid. & Tikali & Araceae & Abundant \\
\hline 96 & Synedrella nodiflora (L.) Gaertn. & & Compositae & Abundant \\
\hline 97 & Themeda quadrivalvis (L.) Kuntze & & Poaceae & Common \\
\hline
\end{tabular}




\begin{tabular}{|c|c|c|c|c|}
\hline No. & Scientific Names & Common Name & Family & Occurrence \\
\hline 98 & Tithonia rotundifolia (Mill.) S.F.Blake & & Compositae & Common \\
\hline 99 & Trianthema portulacastrum L. & & Aizoaceae & Occasional \\
\hline 100 & Tridax procumbens (L.) L. & Ekdandi & Compositae & Common \\
\hline 101 & Triumfetta rhomboidea Jacq. & & Malvaceae & Common \\
\hline 102 & Typha angustifolia L. & Ramban/Pankanis & Typhaceae & Common \\
\hline 103 & Urena lobata $L$. & & Malvaceae & Occasional \\
\hline 104 & Verbascum chinense (L.) Santapau & Kutaki & Scrophulariaceae & Occasional \\
\hline 105 & Wedelia triloba (L.) Hitchc. & Wedelia & Compositae & Occasional \\
\hline 106 & Withania somnifera (L.) Dunal. & Ashwagndha & Solanaceae & Common \\
\hline 107 & Xanthium strumarium L. & Shankeshwar & Compositae & Common \\
\hline \multicolumn{5}{|c|}{ Shrubs } \\
\hline 1 & Calotropis gigantea (L.) Dryand. & Rui & Apocynaceae & Occasional \\
\hline 2 & Chrozophora rottleri (Geiseler) A.Juss. ex Spreng. & Suryvarti & Euphorbiaceae & Common \\
\hline 3 & Dalbergia melanoxylon Guill. \& Perr. & Patangi & Leguminosae & Common \\
\hline 4 & Grewia hirsuta Vahl & & Malvaceae & Rare \\
\hline 5 & Homonoia riparia Lour. & Sherani & Euphorbiaceae & Occasional \\
\hline 6 & Ipomoea carnea Jacq. & Besharam & Convolvulaceae & Common \\
\hline 7 & Lantana camara L. & Tantani & Verbanaceae & Common \\
\hline 8 & Phyllanthus reticulatus Poir. & Panjuli & Phyllanthaceae & Common \\
\hline 9 & Pluchea ovalis (Pers.) DC. & & Compositae & Occasional \\
\hline 10 & Pseudarthria viscida (L.) Wight \& Arn. & & Leguminosae & Common \\
\hline 11 & Ricinus communis L. & Erand & Euphorbiaceae & Common \\
\hline 12 & Sesbania sesban (L.) Merr. & Shevari & Leguminosae & Common \\
\hline 13 & Solanum torvum Sw. & Kutri & Solanaceae & Occasional \\
\hline 14 & Vitex negundo L. & Nirgudi & Lamiaceae & Occasional \\
\hline 15 & Woodfordia fruticosa (L.) Kurz & Dhayati & Lythraceae & Occasional \\
\hline \multicolumn{5}{|c|}{ Climbers } \\
\hline 1 & Argyreia nervosa (Burm.f.) Bojer & Samusrashok & Convolvulaceae & Occasional \\
\hline 2 & Capparis zeylanica $L$. & Govindi & Capparaceae & Occasional \\
\hline 3 & Cardiospermum halicacabum L. & & Sapindaceae & Occasional \\
\hline 4 & Celastrus paniculatus Willd. & Malkangoni & Celastraceae & Occasional \\
\hline 5 & Coccinea grandis (L.)Voigt & Tondali & Cucurbitaceae & Common \\
\hline 6 & Cocculus hirsutus (L.) W.Theob. & Vasanwel & Menispermaceae & Common \\
\hline
\end{tabular}




\begin{tabular}{|c|l|l|l|l|}
\hline No. & Scientific Names & Common Name & Family & Occurrence \\
\hline 7 & Combretum ovalifolium Roxb. & Piluki & Combretaceae & Occasional \\
\hline 8 & Cryptolepis dubia (Burm.f.) M.R.Almeida & Kavali & Apocynaceae & Occasional \\
\hline 9 & Cryptostegia grandiflora Roxb. ex R.Br. & & Apocynaceae & Occasional \\
\hline 10 & Diplocyclos palmatus (L.) Jeffrey. & Shivlingi & Cucurbitaceae & Occasional \\
\hline 11 & Ipomoea cairica (L.) Sweet & $\begin{array}{l}\text { Railway } \\
\text { creeper.Garwel }\end{array}$ & Convolvulaceae & Common \\
\hline 12 & Ipomoea nil (L.) Roth & & Convolvulaceae & Occasional \\
\hline 13 & Ipomoea obscura (L.) Ker Gaww. & & Convolvulaceae & Occasional \\
\hline 14 & Ipomoea triloba L. & & Convolvulaceae & Common \\
\hline 15 & Macroptilium atropurpureum (DC.) Urb. & & Leguminosae & Occasional \\
\hline 16 & Mukia maderaspatana (L.)M.Roem. & Chirati & Cucurbitaceae & Occasional \\
\hline 17 & Passiflora foetida L & Welghani & Passifloraceae & Common \\
\hline 18 & Pergularia daemia (Forsskal) Chiov. & Utran & Apocynaceae & Occasional \\
\hline 19 & Teramnus labialis (L.f.) Spreng. & & Leguminosae & Occasional \\
\hline 20 & Tinospora cordifolia(willd.)Miers. & Gulwel & Menispermaceae & Common \\
\hline 21 & Vigna radiata (L.) R.Wilczek & Moong & Leguminosae & Occasional \\
\hline 22 & Ziziphus oenopolia (L.) Mill. & & Rhamnaceae & Occasional \\
\hline
\end{tabular}


Zones

\begin{tabular}{|c|c|c|c|c|c|c|c|}
\hline No & Botanical name & 1.1 & 1.2 & 2 & 3 & 4 & 5 \\
\hline 1 & Abutilon indicum (L.) Sweet & $\checkmark$ & & $\checkmark$ & $\checkmark$ & $\checkmark$ & $\checkmark$ \\
\hline 2 & Acacia auriculiformis Benth. & $\checkmark$ & $\checkmark$ & $\checkmark$ & & $\checkmark$ & $\checkmark$ \\
\hline 3 & Acacia chundra (Rottler) Willd. & & & & & $\checkmark$ & $\checkmark$ \\
\hline 4 & Acacia nilotica (L.) Delile & $\checkmark$ & $\checkmark$ & $\checkmark$ & $\checkmark$ & $\checkmark$ & $\checkmark$ \\
\hline 5 & Acacia polyacantha Willd. & $\checkmark$ & & $\checkmark$ & & & $\checkmark$ \\
\hline 6 & Acalypha ciliata Forssk. & $\checkmark$ & $\checkmark$ & $\checkmark$ & $\checkmark$ & $\checkmark$ & $\checkmark$ \\
\hline 7 & Achyranthes aspera L. & $\checkmark$ & $\checkmark$ & $\checkmark$ & $\checkmark$ & $\checkmark$ & $\checkmark$ \\
\hline 8 & Adansonia digitata $\mathrm{L}$. & & & & & & $\checkmark$ \\
\hline 9 & Aegle marmelos (L.) Corrêa & & & & & & $\checkmark$ \\
\hline 10 & Aeschynomene indica L. & $\checkmark$ & $\checkmark$ & $\checkmark$ & & $\checkmark$ & $\checkmark$ \\
\hline 11 & Ageratum conyzoides (L.) L. & $\checkmark$ & $\checkmark$ & $\checkmark$ & $\checkmark$ & $\checkmark$ & $\checkmark$ \\
\hline 12 & Albizia lebbeck (L.) Benth. & $\checkmark$ & & $\checkmark$ & & $\checkmark$ & $\checkmark$ \\
\hline 13 & Ailanthus excelsa Roxb. & & & & & $\checkmark$ & \\
\hline 14 & Albizia saman (Jacq.) Merr. & $\checkmark$ & $\checkmark$ & $\checkmark$ & $\checkmark$ & $\checkmark$ & $\checkmark$ \\
\hline 15 & Alstonia scholaris (L.) R.Br. & & $\checkmark$ & $\checkmark$ & & $\checkmark$ & $\checkmark$ \\
\hline 16 & Alternanthera philoxeroides (Mart.) Griseb. & $\checkmark$ & $\checkmark$ & $\checkmark$ & $\checkmark$ & $\checkmark$ & $\checkmark$ \\
\hline 17 & Alternanthera pungens Kunth & & $\checkmark$ & & & & $\checkmark$ \\
\hline 18 & Alternanthera sessilis (L.) R.Br. ex DC. & $\checkmark$ & $\checkmark$ & $\checkmark$ & $\checkmark$ & $\checkmark$ & $\checkmark$ \\
\hline 19 & Alysicarpus tetragonolobus Edgew. & $\checkmark$ & & $\checkmark$ & & $\checkmark$ & $\checkmark$ \\
\hline 20 & Amaranthus spinosus L. & $\checkmark$ & $\checkmark$ & $\checkmark$ & $\checkmark$ & $\checkmark$ & $\checkmark$ \\
\hline 21 & Amaranthus viridis L. & $\checkmark$ & $\checkmark$ & $\checkmark$ & $\checkmark$ & $\checkmark$ & $\checkmark$ \\
\hline 22 & Ammannia baccifera $\mathrm{L}$. & $\checkmark$ & & & & $\checkmark$ & \\
\hline 23 & Annona squamosa $\mathrm{L}$ & $\checkmark$ & $\checkmark$ & & & & $\checkmark$ \\
\hline 24 & Apluda mutica L. & $\checkmark$ & & & & $\checkmark$ & $\checkmark$ \\
\hline 25 & Argemone mexicana $\mathrm{L}$. & $\checkmark$ & $\checkmark$ & $\checkmark$ & $\checkmark$ & $\checkmark$ & $\checkmark$ \\
\hline 26 & Argyreia nervosa (Burm. f.) Bojer & $\checkmark$ & & & & $\checkmark$ & $\checkmark$ \\
\hline 27 & Asclepias curassavica L. & $\checkmark$ & $\checkmark$ & $\checkmark$ & $\checkmark$ & $\checkmark$ & $\checkmark$ \\
\hline 28 & Azadirachta indica A.Juss. & $\checkmark$ & $\checkmark$ & $\checkmark$ & $\checkmark$ & $\checkmark$ & $\checkmark$ \\
\hline 29 & Azolla pinnata $\mathrm{R}$. Br. & $\checkmark$ & $\checkmark$ & & & $\checkmark$ & $\checkmark$ \\
\hline 30 & Bacopa monnieri (L.) Wettst. & $\checkmark$ & & & & & $\checkmark$ \\
\hline 31 & Bambusa vulgaris Schrad. & $\checkmark$ & & $\checkmark$ & & & \\
\hline 32 & Bauhinia purpurea L. & $\checkmark$ & & & $\checkmark$ & $\checkmark$ & \\
\hline 33 & Bidens biternata (Lour.) Merr. \& Sherff & $\checkmark$ & $\checkmark$ & $\checkmark$ & & $\checkmark$ & $\checkmark$ \\
\hline 34 & Boerhavia diffusa L. & $\checkmark$ & & $\checkmark$ & & $\checkmark$ & $\checkmark$ \\
\hline 35 & Bombax ceiba L. & $\checkmark$ & & $\checkmark$ & & $\checkmark$ & $\checkmark$ \\
\hline 36 & Brassica juncea (L.) Czern. & $\checkmark$ & $\checkmark$ & $\checkmark$ & $\checkmark$ & $\checkmark$ & \\
\hline 37 & Broussonetia papyrifera (L.) Vent & $\checkmark$ & $\checkmark$ & & & $\checkmark$ & \\
\hline 38 & Calotropis gigantea (L.) Dryand. & $\checkmark$ & $\checkmark$ & $\checkmark$ & $\checkmark$ & $\checkmark$ & $\checkmark$ \\
\hline 39 & Canna indica $\mathrm{L}$. & $\checkmark$ & & & $\checkmark$ & $\checkmark$ & \\
\hline 40 & Carica papaya L. & $\checkmark$ & & & & $\checkmark$ & \\
\hline 41 & Canscora diffusa (Vahl) R.Br. ex Roem. \& Schult. & $\checkmark$ & & $\checkmark$ & & $\checkmark$ & \\
\hline 42 & Capparis zeylanica $\mathrm{L}$. & $\checkmark$ & & & & $\checkmark$ & \\
\hline 43 & Capparris grandis L.f. & & $\checkmark$ & $\checkmark$ & $\checkmark$ & $\checkmark$ & $\checkmark$ \\
\hline 44 & Cardiospermum halicacabum L. & $\checkmark$ & $\checkmark$ & $\checkmark$ & & & $\checkmark$ \\
\hline 45 & Celastrus paniculatus Willd. & $\checkmark$ & & & & $\checkmark$ & \\
\hline 46 & Celosia argentea $\mathrm{L}$. & $\checkmark$ & & $\checkmark$ & $\checkmark$ & $\checkmark$ & $\checkmark$ \\
\hline
\end{tabular}


Zones

\begin{tabular}{|c|c|c|c|c|c|c|c|}
\hline No & Botanical name & 1.1 & 1.2 & 2 & 3 & 4 & 5 \\
\hline 47 & Centella asiatica (L.) Urb. & $\checkmark$ & & & & & \\
\hline 48 & Chloris virgata Sw. & $\checkmark$ & $\checkmark$ & $\checkmark$ & $\checkmark$ & $\checkmark$ & $\checkmark$ \\
\hline 49 & Chromolaena odorata (L.) R.M.King\& H.Rob. & $\checkmark$ & $\checkmark$ & $\checkmark$ & $\checkmark$ & $\checkmark$ & $\checkmark$ \\
\hline 50 & Chrozophora rottleri (Geiseler) A.Juss. ex Spreng. & $\checkmark$ & $\checkmark$ & $\checkmark$ & $\checkmark$ & & $\checkmark$ \\
\hline 51 & Cleome rutidosperma DC. & $\checkmark$ & & & & & \\
\hline 52 & Cleome viscosa $\mathrm{L}$. & $\checkmark$ & & & & $\checkmark$ & $\checkmark$ \\
\hline 53 & Coccinea grandis (L.)Voigt & $\checkmark$ & $\checkmark$ & $\checkmark$ & $\checkmark$ & $\checkmark$ & $\checkmark$ \\
\hline 54 & Cocculus hirsutus (L.) W.Theob. & $\checkmark$ & $\checkmark$ & $\checkmark$ & $\checkmark$ & $\checkmark$ & $\checkmark$ \\
\hline 55 & Cocos nucifera L. & $\checkmark$ & $\checkmark$ & & $\checkmark$ & $\checkmark$ & \\
\hline 56 & Colocassia esculenta (L.) Scott & $\checkmark$ & & $\checkmark$ & $\checkmark$ & $\checkmark$ & \\
\hline 57 & Combretum ovalifolium Roxb. & $\checkmark$ & $\checkmark$ & $\checkmark$ & & $\checkmark$ & $\checkmark$ \\
\hline 58 & Commelina benghalensis L. & $\checkmark$ & $\checkmark$ & $\checkmark$ & & $\checkmark$ & $\checkmark$ \\
\hline 59 & Commelina caroliniana Walter & $\checkmark$ & & & & $\checkmark$ & $\checkmark$ \\
\hline 60 & Corchorus sp. & $\checkmark$ & $\checkmark$ & $\checkmark$ & & $\checkmark$ & $\checkmark$ \\
\hline 61 & Cordia dichotoma G.Forst. & $\checkmark$ & $\checkmark$ & $\checkmark$ & & $\checkmark$ & \\
\hline 62 & Cosmos sulphureus Cav. & $\checkmark$ & $\checkmark$ & & & $\checkmark$ & \\
\hline 63 & Couroupita guianensis Aubl. & & & $\checkmark$ & & $\checkmark$ & \\
\hline 64 & Croton bonplandianus Baill. & & $\checkmark$ & & & $\checkmark$ & $\checkmark$ \\
\hline 65 & Cryptolepis dubia (Burm.f.) M.R.Almeida & $\checkmark$ & $\checkmark$ & $\checkmark$ & & $\checkmark$ & $\checkmark$ \\
\hline 66 & Cryptostegia grandiflora Roxb. ex R.Br. & $\checkmark$ & $\checkmark$ & $\checkmark$ & & $\checkmark$ & $\checkmark$ \\
\hline 67 & Cullen corylifolium (L.) Medik. & $\checkmark$ & & & $\checkmark$ & $\checkmark$ & \\
\hline 68 & Cyanotis fasciculata (B.Heyne ex Roth) Schult. \& Schult.f. & $\checkmark$ & & & & & $\checkmark$ \\
\hline 69 & Cyanthillium cinereum (L.) H.Rob. & $\checkmark$ & $\checkmark$ & $\checkmark$ & & $\checkmark$ & $\checkmark$ \\
\hline 70 & Cynodon dactylon (L.) Pers. & $\checkmark$ & $\checkmark$ & $\checkmark$ & $\checkmark$ & $\checkmark$ & $\checkmark$ \\
\hline 71 & Cyperus scariosus R.Br. & $\checkmark$ & $\checkmark$ & & & & $\checkmark$ \\
\hline 72 & Dactyloctenium aegyptium (L.) Willd. & $\checkmark$ & $\checkmark$ & $\checkmark$ & & $\checkmark$ & $\checkmark$ \\
\hline 73 & Dalbergia melanoxylon Guill. \& Perr. & & & & & & $\checkmark$ \\
\hline 74 & Dalbergia sissoo DC. & & $\checkmark$ & $\checkmark$ & & & $\checkmark$ \\
\hline 75 & Datura innoxia Mill. & $\checkmark$ & $\checkmark$ & $\checkmark$ & $\checkmark$ & $\checkmark$ & $\checkmark$ \\
\hline 76 & Datura metel L. & & & & $\checkmark$ & & \\
\hline 77 & Delonix regia (Hook.) Raf. & & & & $\checkmark$ & & $\checkmark$ \\
\hline 78 & Desmodium tortuosum (Sw.) DC. & $\checkmark$ & $\checkmark$ & & & & $\checkmark$ \\
\hline 79 & Digitaria ciliaris (Retz.) Koeler & & $\checkmark$ & $\checkmark$ & & $\checkmark$ & $\checkmark$ \\
\hline 80 & Dinebra retroflexa (Vahl) Panz. & $\checkmark$ & $\checkmark$ & & & $\checkmark$ & $\checkmark$ \\
\hline 81 & Diplocyclos palmatus (L.) Jeffrey. & $\checkmark$ & & & $\checkmark$ & $\checkmark$ & $\checkmark$ \\
\hline 82 & Echinochloa colona (L.) Link & $\checkmark$ & $\checkmark$ & $\checkmark$ & & $\checkmark$ & $\checkmark$ \\
\hline 83 & Eclipta prostrata (L.) L. & $\checkmark$ & $\checkmark$ & $\checkmark$ & & $\checkmark$ & \\
\hline 84 & Eichhornia crassipes (Mart.) Solms & $\checkmark$ & $\checkmark$ & $\checkmark$ & $\checkmark$ & $\checkmark$ & $\checkmark$ \\
\hline 85 & Emilia sonchifolia (L.) DC. ex DC. & $\checkmark$ & $\checkmark$ & & & & $\checkmark$ \\
\hline 86 & Eucalyptus globulus Labill. & & $\checkmark$ & $\checkmark$ & & $\checkmark$ & $\checkmark$ \\
\hline 87 & Euphorbia heterophylla L. & $\checkmark$ & $\checkmark$ & $\checkmark$ & $\checkmark$ & $\checkmark$ & $\checkmark$ \\
\hline 88 & Euphorbia hypericifolia L. & $\checkmark$ & & & & & \\
\hline 89 & Exacum pedunculatum L. & $\checkmark$ & & & & & \\
\hline 90 & Ficus benghalensis L. & $\checkmark$ & & $\checkmark$ & & $\checkmark$ & $\checkmark$ \\
\hline 91 & Ficus hispida L. f. & $\checkmark$ & & $\checkmark$ & $\checkmark$ & $\checkmark$ & $\checkmark$ \\
\hline 92 & Ficus racemosa $\mathrm{L}$. & $\checkmark$ & $\checkmark$ & $\checkmark$ & $\checkmark$ & $\checkmark$ & $\checkmark$ \\
\hline 93 & Ficus religiosa $\mathrm{L}$. & $\checkmark$ & $\checkmark$ & $\checkmark$ & $\checkmark$ & $\checkmark$ & $\checkmark$ \\
\hline 94 & Gliricidia sepium (Jacq.) Walp. & $\checkmark$ & $\checkmark$ & $\checkmark$ & $\checkmark$ & $\checkmark$ & $\checkmark$ \\
\hline
\end{tabular}


Zones

\begin{tabular}{|c|c|c|c|c|c|c|c|}
\hline No & Botanical name & 1.1 & 1.2 & 2 & 3 & 4 & 5 \\
\hline 95 & Glinus lotoides L. & $\checkmark$ & & & & & \\
\hline 96 & Gmelina arborea Roxb. & & & & & & \\
\hline 97 & Gomphrena sp. & $\checkmark$ & & & & & \\
\hline 98 & Grangea maderaspatana (L.) Poir. & $\checkmark$ & $\checkmark$ & & & & \\
\hline 99 & Grewia hirsuta Vahl & $\checkmark$ & & & & & \\
\hline 100 & Grewia tilifolia Vahl. & $\checkmark$ & & & & $\checkmark$ & $\checkmark$ \\
\hline 101 & Gynandropsis pentaphylla (L.) & & & $\checkmark$ & & $\checkmark$ & \\
\hline 102 & Heliotropium indicum L. & $\checkmark$ & $\checkmark$ & & & $\checkmark$ & $\checkmark$ \\
\hline 103 & Hibiscus sp. & & $\checkmark$ & $\checkmark$ & & & \\
\hline 104 & Holoptelea integrifolia Planch. & $\checkmark$ & $\checkmark$ & $\checkmark$ & $\checkmark$ & $\checkmark$ & $\checkmark$ \\
\hline 105 & Homonoia riparia Lour. & $\checkmark$ & & & & & $\checkmark$ \\
\hline 106 & Hygrophila auriculata (Schumach.) Heine & $\checkmark$ & $\checkmark$ & $\checkmark$ & & $\checkmark$ & $\checkmark$ \\
\hline 107 & Hyptis suaveolens (L.) Poit. & $\checkmark$ & $\checkmark$ & $\checkmark$ & & $\checkmark$ & $\checkmark$ \\
\hline 108 & Indigofera glandulosa Wendl. & $\checkmark$ & & & & & \\
\hline 109 & Ipomoea aquatica Forssk. & $\checkmark$ & $\checkmark$ & & & & \\
\hline 110 & Ipomoea cairica (L.) Sweet & $\checkmark$ & $\checkmark$ & & $\checkmark$ & $\checkmark$ & $\checkmark$ \\
\hline 111 & Ipomoea carnea Jacq. & $\checkmark$ & $\checkmark$ & $\checkmark$ & $\checkmark$ & $\checkmark$ & $\checkmark$ \\
\hline 112 & Ipomoea obscura (L.) Ker Gawl. & $\checkmark$ & & & & & \\
\hline 113 & Ipomoea triloba L. & $\checkmark$ & $\checkmark$ & $\checkmark$ & & $\checkmark$ & $\checkmark$ \\
\hline 114 & Ipomoea nil (L.) Roth & & & & & $\checkmark$ & $\checkmark$ \\
\hline 115 & Lagascea mollis Cav. & $\checkmark$ & & & & & \\
\hline 116 & Lantana camara L. & $\checkmark$ & $\checkmark$ & $\checkmark$ & $\checkmark$ & $\checkmark$ & $\checkmark$ \\
\hline 117 & Launaea procumbens (Roxb.) Ramayya \& Rajagopal & & $\checkmark$ & $\checkmark$ & & $\checkmark$ & $\checkmark$ \\
\hline 118 & Lemna gibba L. & $\checkmark$ & $\checkmark$ & & $\checkmark$ & $\checkmark$ & $\checkmark$ \\
\hline 119 & Leucaena leucocephala (Lam.) de Wit & $\checkmark$ & $\checkmark$ & $\checkmark$ & $\checkmark$ & $\checkmark$ & $\checkmark$ \\
\hline 120 & Leucas biflora (Vahl) Sm. & $\checkmark$ & & & & & $\checkmark$ \\
\hline 121 & Leucas longifolia Benth. & $\checkmark$ & $\checkmark$ & $\checkmark$ & & $\checkmark$ & \\
\hline 122 & Limonia acidissima Groff & $\checkmark$ & & & & & \\
\hline 123 & Ludwigia octovalvis (Jacq.) P.H.Raven & $\checkmark$ & $\checkmark$ & $\checkmark$ & $\checkmark$ & $\checkmark$ & $\checkmark$ \\
\hline 124 & Leonotis nepetifolia (L.) R.Br. & $\checkmark$ & & & & $\checkmark$ & $\checkmark$ \\
\hline 125 & Macroptilium atropurpureum (DC.) Urb. & $\checkmark$ & & & & & \\
\hline 126 & Mangifera indica $\mathrm{L}$ & $\checkmark$ & $\checkmark$ & $\checkmark$ & & $\checkmark$ & \\
\hline 127 & Martynia annua L. & $\checkmark$ & $\checkmark$ & $\checkmark$ & & $\checkmark$ & \\
\hline 128 & Millingtonia hortensis L.fil. & $\checkmark$ & $\checkmark$ & $\checkmark$ & & & $\checkmark$ \\
\hline 129 & Mimusops elengi L. & & & $\checkmark$ & & & $\checkmark$ \\
\hline 130 & Mollugo pentaphylla L. & $\checkmark$ & & & & & \\
\hline 131 & Morinda pubescens Sm. & $\checkmark$ & $\checkmark$ & $\checkmark$ & & $\checkmark$ & $\checkmark$ \\
\hline 132 & Moringa oleifera Lam. & $\checkmark$ & & & $\checkmark$ & $\checkmark$ & \\
\hline 133 & Mukia maderaspatana (L.)M.Roem. & $\checkmark$ & $\checkmark$ & $\checkmark$ & & & \\
\hline 134 & Muntingia calabura L. & $\checkmark$ & $\checkmark$ & $\checkmark$ & & $\checkmark$ & $\checkmark$ \\
\hline 135 & Neolamarckia cadamba (Roxb.) Bosser & $\checkmark$ & $\checkmark$ & $\checkmark$ & & & \\
\hline 136 & Ocimum gratissimum $\mathrm{L}$. & $\checkmark$ & & & & & \\
\hline 137 & Oldenlandia corymbosa $\mathrm{L}$. & $\checkmark$ & & & & & $\checkmark$ \\
\hline 138 & Oxalis corniculata $\mathrm{L}$. & $\checkmark$ & $\checkmark$ & $\checkmark$ & $\checkmark$ & $\checkmark$ & $\checkmark$ \\
\hline 139 & Parthenium hysterophorus L. & $\checkmark$ & $\checkmark$ & $\checkmark$ & $\checkmark$ & $\checkmark$ & $\checkmark$ \\
\hline 140 & Passiflora foetida $\mathrm{L}$ & $\checkmark$ & $\checkmark$ & $\checkmark$ & & $\checkmark$ & $\checkmark$ \\
\hline 141 & Peltoforum pterocarpum Auct. non K.Heyne & & $\checkmark$ & $\checkmark$ & $\checkmark$ & $\checkmark$ & $\checkmark$ \\
\hline 142 & Pergularia daemia (Forsskal) Chiov. & $\checkmark$ & & & & $\checkmark$ & $\checkmark$ \\
\hline
\end{tabular}


Zones

\begin{tabular}{|c|c|c|c|c|c|c|c|}
\hline No & Botanical name & 1.1 & 1.2 & 2 & 3 & 4 & 5 \\
\hline 143 & Persicaria glabra (Willd.) M.Gómez & $\checkmark$ & $\checkmark$ & $\checkmark$ & $\checkmark$ & $\checkmark$ & $\checkmark$ \\
\hline 144 & Phoenix sylvestris (L.) Roxb. & $\checkmark$ & $\checkmark$ & & & $\checkmark$ & $\checkmark$ \\
\hline 145 & Phyla nodiflora (L.) Greene & $\checkmark$ & & & & & $\checkmark$ \\
\hline 146 & Phyllanthus niruri L. & $\checkmark$ & $\checkmark$ & & $\checkmark$ & $\checkmark$ & $\checkmark$ \\
\hline 147 & Phyllanthus reticulatus Poir. & $\checkmark$ & $\checkmark$ & $\checkmark$ & & $\checkmark$ & $\checkmark$ \\
\hline 148 & Physalis minima L. & $\checkmark$ & $\checkmark$ & & & & \\
\hline 149 & Pistia stratiotes L. & $\checkmark$ & $\checkmark$ & $\checkmark$ & $\checkmark$ & $\checkmark$ & $\checkmark$ \\
\hline 150 & Pithecellobium dulce (Roxb.)Benth. & $\checkmark$ & $\checkmark$ & $\checkmark$ & $\checkmark$ & $\checkmark$ & $\checkmark$ \\
\hline 151 & Pluchea ovalis (Pers.) DC. & $\checkmark$ & & $\checkmark$ & & $\checkmark$ & \\
\hline 152 & Plumbago zeylanica L. & $\checkmark$ & $\checkmark$ & $\checkmark$ & $\checkmark$ & & $\checkmark$ \\
\hline 153 & Polyalthia longifolia (Sonn.) Thwaites & & $\checkmark$ & $\checkmark$ & $\checkmark$ & & \\
\hline 154 & Pongamia pinnata (L.) Pierre & $\checkmark$ & $\checkmark$ & & $\checkmark$ & $\checkmark$ & $\checkmark$ \\
\hline 155 & Portulaca oleracea L. & $\checkmark$ & $\checkmark$ & $\checkmark$ & $\checkmark$ & & \\
\hline 156 & Prosopis juliflora (Sw.) DC & $\checkmark$ & $\checkmark$ & $\checkmark$ & $\checkmark$ & $\checkmark$ & $\checkmark$ \\
\hline 157 & Pseudarthria viscida (L.) Wight \& Arn. & $\checkmark$ & $\checkmark$ & & & & \\
\hline 158 & Psidium guajava L. & $\checkmark$ & $\checkmark$ & & & & $\checkmark$ \\
\hline 159 & Pterospermum acerifolium (L.) Willd. & & & $\checkmark$ & & & $\checkmark$ \\
\hline 160 & Putranjiva roxburghii Wall. & & & $\checkmark$ & & $\checkmark$ & \\
\hline 161 & Ricinus communis L. & $\checkmark$ & $\checkmark$ & $\checkmark$ & $\checkmark$ & $\checkmark$ & $\checkmark$ \\
\hline 162 & Ruelia tuberosa L & & & & $\checkmark$ & & $\checkmark$ \\
\hline 163 & Salix tetrasperma Roxb. & & & & & $\checkmark$ & $\checkmark$ \\
\hline 164 & Santalum album $\mathrm{L}$. & $\checkmark$ & $\checkmark$ & & & $\checkmark$ & $\checkmark$ \\
\hline 165 & Senna siamea (Lam.) H.S.Irwin\& Barneby & $\checkmark$ & $\checkmark$ & $\checkmark$ & $\checkmark$ & $\checkmark$ & $\checkmark$ \\
\hline 166 & Senna sophera (L.) Roxb. & & & $\checkmark$ & & $\checkmark$ & \\
\hline 167 & Senna tora (L.) Roxb. & $\checkmark$ & $\checkmark$ & $\checkmark$ & $\checkmark$ & $\checkmark$ & $\checkmark$ \\
\hline 168 & Senna uniflora (Mill.) H.S.Irwin\& Barneby & $\checkmark$ & $\checkmark$ & $\checkmark$ & $\checkmark$ & $\checkmark$ & $\checkmark$ \\
\hline 169 & Sesamum orientale L. & $\checkmark$ & & & $\checkmark$ & & $\checkmark$ \\
\hline 170 & Sesbania sesban (L.) Merr. & $\checkmark$ & & $\checkmark$ & & & \\
\hline 171 & Setaria viridis (L.) P.Beauv. & $\checkmark$ & $\checkmark$ & $\checkmark$ & $\checkmark$ & $\checkmark$ & $\checkmark$ \\
\hline 172 & Sida acuta Burm.f. & $\checkmark$ & $\checkmark$ & $\checkmark$ & $\checkmark$ & $\checkmark$ & $\checkmark$ \\
\hline 173 & Solanum lycopersicum L. & $\checkmark$ & $\checkmark$ & & $\checkmark$ & & $\checkmark$ \\
\hline 174 & Solanum nigrum L. & $\checkmark$ & & & & & $\checkmark$ \\
\hline 175 & Solanum toroum Sw. & $\checkmark$ & $\checkmark$ & $\checkmark$ & $\checkmark$ & $\checkmark$ & $\checkmark$ \\
\hline 176 & Solanum virginianum L. & $\checkmark$ & $\checkmark$ & & $\checkmark$ & & \\
\hline 177 & Sonchus oleraceus (L.) L. & $\checkmark$ & $\checkmark$ & $\checkmark$ & & & $\checkmark$ \\
\hline 178 & Spathodea campanulata P.Beauv. & $\checkmark$ & $\checkmark$ & $\checkmark$ & & & $\checkmark$ \\
\hline 179 & Spermacoce pusilla Wall. & $\checkmark$ & $\checkmark$ & $\checkmark$ & & & $\checkmark$ \\
\hline 180 & Spilanthes acmella (L.) L. & $\checkmark$ & & & & $\checkmark$ & $\checkmark$ \\
\hline 181 & Spirodela polyrrhiza (L.) Schleid. & $\checkmark$ & $\checkmark$ & & & & \\
\hline 182 & Sterculia foetida L. & & $\checkmark$ & $\checkmark$ & $\checkmark$ & & $\checkmark$ \\
\hline 183 & Synedrella nodiflora (L.) Gaertn. & $\checkmark$ & $\checkmark$ & $\checkmark$ & $\checkmark$ & $\checkmark$ & $\checkmark$ \\
\hline 184 & Syzygium cumini (L.) Skeels & $\checkmark$ & $\checkmark$ & & & $\checkmark$ & $\checkmark$ \\
\hline 185 & Syzygium heyneanum (Duthie)Wall.ex Gamble & & & & & & $\checkmark$ \\
\hline 186 & Tamarindus indica L. & $\checkmark$ & $\checkmark$ & & & $\checkmark$ & $\checkmark$ \\
\hline 187 & Teramnus labialis (L.f.) Spreng. & $\checkmark$ & $\checkmark$ & & & & $\checkmark$ \\
\hline 188 & Terminalia arjuna (Roxb. ex DC.) Wight \& Arn. & $\checkmark$ & $\checkmark$ & & $\checkmark$ & & \\
\hline 189 & Terminalia catappa L. & & $\checkmark$ & $\checkmark$ & $\checkmark$ & $\checkmark$ & $\checkmark$ \\
\hline 190 & Terminalia cuneata Roth & & & & & & \\
\hline
\end{tabular}


Zones

\begin{tabular}{|c|c|c|c|c|c|c|c|}
\hline No & Botanical name & 1.1 & 1.2 & 2 & 3 & 4 & 5 \\
\hline 191 & Themeda quadrivalvis (L.) Kuntze & & & & & & $\checkmark$ \\
\hline 192 & Tinospora cordifolia (willd.)Miers. & $\checkmark$ & & $\checkmark$ & & & $\checkmark$ \\
\hline 193 & Tithonia rotundifolia (Mill.) S.F.Blake & $\checkmark$ & & & & & $\checkmark$ \\
\hline 194 & Trema orientalis (L.) Blume & $\checkmark$ & $\checkmark$ & $\checkmark$ & $\checkmark$ & $\checkmark$ & $\checkmark$ \\
\hline 195 & Trianthema portulacastrum L. & $\checkmark$ & & & & & $\checkmark$ \\
\hline 196 & Tridax procumbens (L.) L. & $\checkmark$ & $\checkmark$ & $\checkmark$ & $\checkmark$ & $\checkmark$ & $\checkmark$ \\
\hline 197 & Triumfetta rhomboidea Jacq. & $\checkmark$ & $\checkmark$ & & & & $\checkmark$ \\
\hline 198 & Typha angustifolia L. & $\checkmark$ & $\checkmark$ & & & $\checkmark$ & $\checkmark$ \\
\hline 199 & Urena lobata L. & $\checkmark$ & $\checkmark$ & & & $\checkmark$ & $\checkmark$ \\
\hline 200 & Verbascum chinense (L.) Santapau & $\checkmark$ & $\checkmark$ & $\checkmark$ & & $\checkmark$ & \\
\hline 201 & Vigna radiata (L.) R.Wilczek & $\checkmark$ & & & & & \\
\hline 202 & Vitex negundo L. & $\checkmark$ & $\checkmark$ & $\checkmark$ & & & $\checkmark$ \\
\hline 203 & Wedelia triloba (L.) Hitchc. & $\checkmark$ & & & & $\checkmark$ & \\
\hline 204 & Withania somnifera (L.) Dunal. & $\checkmark$ & $\checkmark$ & $\checkmark$ & $\checkmark$ & $\checkmark$ & $\checkmark$ \\
\hline 205 & Woodfordia fruticosa (L.) Kurz & $\checkmark$ & & & & & \\
\hline 206 & Xanthium strumarium L. & $\checkmark$ & $\checkmark$ & $\checkmark$ & $\checkmark$ & $\checkmark$ & $\checkmark$ \\
\hline 207 & Ziziphus oenopolia (L.) Mill. & $\checkmark$ & & & & $\checkmark$ & $\checkmark$ \\
\hline 208 & Zizipus mauritiana Lamk. & $\checkmark$ & $\checkmark$ & & $\checkmark$ & $\checkmark$ & $\checkmark$ \\
\hline
\end{tabular}

\section{Annexure 3 : Checklist of recommended flora for plantations}

(Refer Figure Typical cross section showing various habitats and the following links for habitats)

Native trees and their habitats http://oikos.in/html/newckfinder/userfiles/files/Grow_Natives_booklet.pdf

Plantation Guidelines refer to http://oikos.in/html/newckfinder/userfiles/files/PlantationsGuidelines.pdf

\section{For Riparian Zone}

\section{Sr.No. Botanical Name}

Trees

$\begin{aligned} 1 & \text { Ficus racemosa } \\ 2 & \text { Pongamia pinnata } \\ 3 & \text { Salix tetrasperma } \\ 4 & \text { Syzygium cumini } \\ 5 & \text { Syzygium heyneanum } \\ 6 & \text { Lagerstroemia speciosa } \\ 7 & \text { Terminalia arjuna } \\ 8 & \text { Neolamarckia cadamba } \\ 9 & \text { Acacia nilotica } \\ 10 & \text { Crataeva adansonii }\end{aligned}$

Shrubs

\section{Vitex negundo}

Phyllanthus retuculatus

Homonoia riparia

Tamarix ericoides

Glycomsis pentaphylla

Woodfordia fruticosa

\section{Local name}

Umbar

Karanj

Walunj

Jambhul

Panjambhul

Tamhan

Arjun

Kadamb

Babhul

Varun

Nirgudi

Panjuli

Sherani

Kadesherani

Kirmira

Dhayati

\section{Sr.No. Botanical Name}

Herbs

1 Canna indica

Coix lacryma-jobi L.

Crinum viviparum

Cyperus difformis

Hygrophila auriculata

Persicaria glabra

Saccharum spontaneum

Typha angustata

Centella asiatica

10 Phyla nodiflora

11

Baccopa moneri

\section{Climbers}

1 Tinospora cordifolia

2 Combratum ovalifolium

3 Argyreia nervosa

\section{Local name}

Kardal

Kashed

Nagdamani

Lavhale

Talimkhana

Paral

Ranus/Kamis

Ramban/

Pankanis

Mandukparni

Jalpimpali

Neerbrahmi

Gulwel

Piluki

Samudraskok 
For Upland habitat

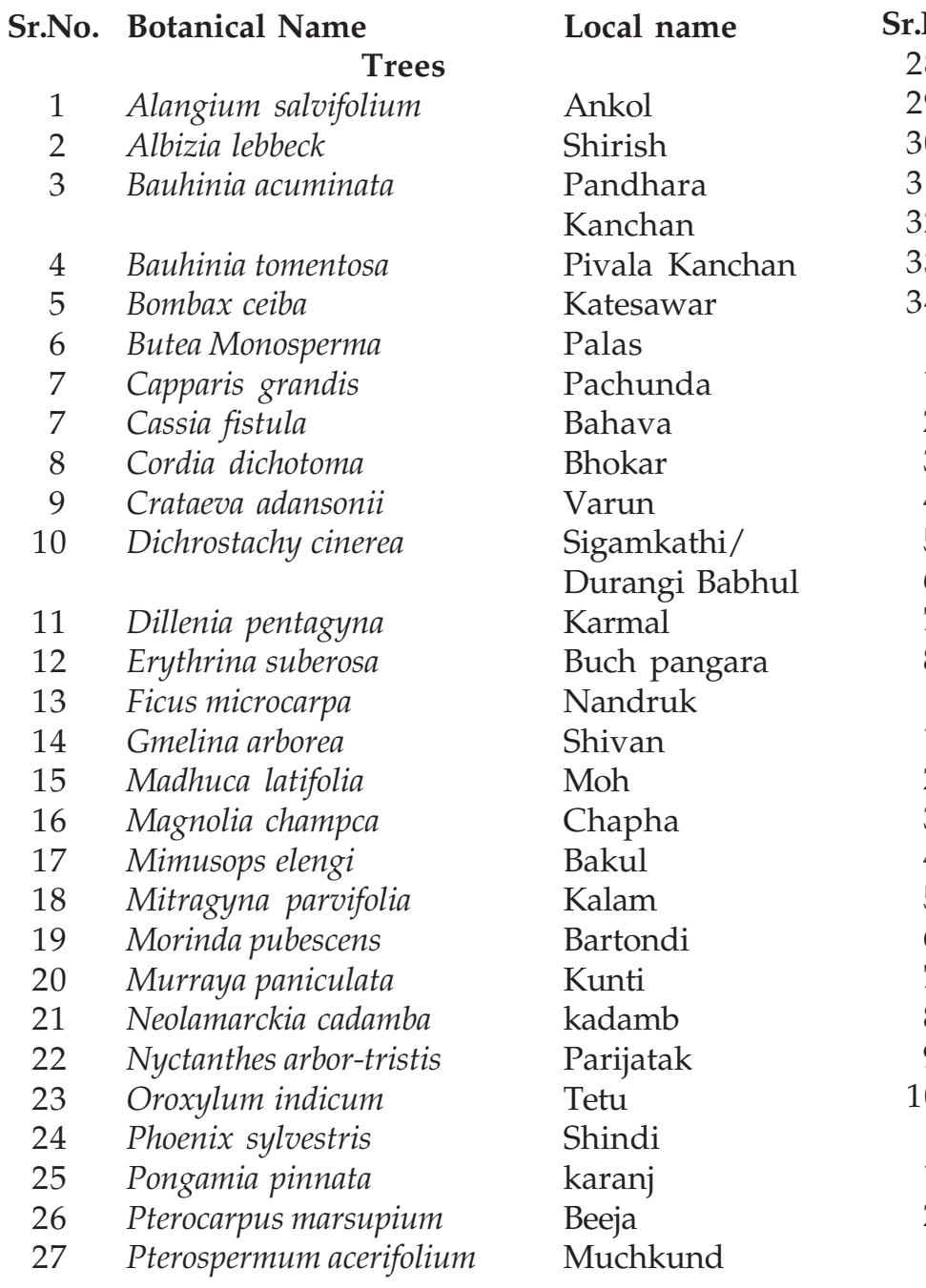

\begin{tabular}{|c|c|c|}
\hline Sr.No. & Botanical Name & Local name \\
\hline 28 & Saraca asoca & Seeta Askok \\
\hline 29 & Schleichera oleosa & Kusum \\
\hline 30 & Sesbania grandiflora & Agasti \\
\hline 31 & Tamilnadia uliginosa & Pendhra \\
\hline 32 & Terminalia bellirica & Beheda \\
\hline 33 & Wrightia arborea & Tambada Kuda \\
\hline 34 & Wrightia tinctoria & Kala Kuda \\
\hline \multicolumn{3}{|c|}{ Shrubs } \\
\hline 1 & Capparis decidua & Nepati \\
\hline 2 & Carrisa congesta & Karvand \\
\hline 3 & Clerodendrum phlomids & Arni \\
\hline 4 & Helicteres isora & Murudsheng \\
\hline 5 & Justicia adhatoda & Adhulasa \\
\hline 6 & Pavetta crassicaulis & Phapat \\
\hline 7 & Vitex nigundo & Nirgudi \\
\hline \multicolumn{3}{|c|}{ Climbers } \\
\hline 1 & Argyreia nervosa & Samudrashok \\
\hline 2 & Aristolochia sp. & Badakwel \\
\hline 3 & Asparagus racemosus & Shatawari \\
\hline 4 & Caesalpinia bonduc & \\
\hline 5 & Cissus quadrangularis & Hadjodi \\
\hline 6 & Clematis gouriana & Ranjai \\
\hline 7 & Gloriosa superba & Kal-lawi \\
\hline 8 & Hiptage benghalensis & Madhumalati \\
\hline 9 & Oxystelma esculentum & Dudhani \\
\hline 10 & Piper longan & Pimpali \\
\hline \multicolumn{3}{|c|}{ Herbs } \\
\hline 1 & Bambusa arundinacea & Kalak(Bamboo) \\
\hline 2 & Dendrocalamus strictus & Mes(Bamboo) \\
\hline
\end{tabular}

\section{References}

Flora of Maharashtra State -Dicotyledones.Vol-1 and 2. Botanical Survey of India

Gole, P. (1983) Survey of the Rivers in Pune City based on Ecological factors to prepare an eco-development plan to improve the River-Fronts of Pune. Ecological Society.

https: / / www.internationalrivers.org/environmentalflows

PMC Environmental Status Report 2016-2017 - PMC Website.

Report. (1998). Stream Corridor Restoration: Principles, Processes and Practices. National Service Center for Environmental Publications (NSCEP). (https:// www.nrcs.usda.gov/Internet/FSE_DOCUMENTS/ stelprdb1044574.pdf

Vartak, V.D. (1958, b ) The study of the Flora of the Mutha River-bed near Poona; Poona Agricultural College Magazine, 48:24-40 and 49; 121-132.

Ghate, Vartak (1981) Studies on the Aquatic Flowering Plants from Greater Pune area : Part I; Journal of University of Poona, Science and Technology Section No. 54, 1981.

Wagh, Ghate -2003, Freshwater Fauna of the Rivers Mula and Mutha, Pune, Maharashtra.January 2003, Zoos Print Journal,18 (1) DOI 10.11609 / JOTT.ZPJ.18.1-977-89

https: / /greentribunal.in

Swati Gole, ( 2014 ), Ecological Guidelines and Recommendations for Mula-Mutha Riverfront Development. - A Report, By Ecological Society, Centre for Environmental Education. 